\title{
Investigation of gaseous and particulate emissions from various marine vessel types measured on the banks of the Elbe in Northern Germany
}

\author{
J.-M. Diesch ${ }^{1}$, F. Drewnick ${ }^{1}$, T. Klimach ${ }^{1}$, and S. Borrmann ${ }^{1,2}$ \\ ${ }^{1}$ Particle Chemistry Department, Max Planck Institute for Chemistry, Mainz, Germany \\ ${ }^{2}$ Institute of Atmospheric Physics, Johannes Gutenberg University Mainz, Mainz, Germany \\ Correspondence to: J.-M. Diesch (jovana.diesch@googlemail.com) and F. Drewnick (frank.drewnick@mpic.de)
}

Received: 25 July 2012 - Published in Atmos. Chem. Phys. Discuss.: 29 August 2012

Revised: 27 February 2013 - Accepted: 28 February 2013 - Published: 2 April 2013

\begin{abstract}
Measurements of the ambient aerosol, various trace gases and meteorological quantities using a mobile laboratory (MoLa) were performed on the banks of the Lower Elbe in an emission control area (ECA) which is passed by numerous private and commercial marine vessels reaching and leaving the port of Hamburg, Germany. From 25-29 April 2011 a total of 178 vessels were probed at a distance of about $0.8-1.2 \mathrm{~km}$ with high temporal resolution. 139 ship emission plumes were of sufficient quality to be analyzed further and to determine emission factors (EFs).

Concentrations of aerosol number and mass as well as polycyclic aromatic hydrocarbons (PAH) and black carbon were measured in $\mathrm{PM}_{1}$ and size distribution instruments covered the diameter range from $6 \mathrm{~nm}$ up to $32 \mu \mathrm{m}$. The chemical composition of the non-refractory submicron aerosol was measured by means of an Aerosol Mass Spectrometer (Aerodyne HR-ToF-AMS). Gas phase species analyzers monitored various trace gases $\left(\mathrm{O}_{3}, \mathrm{SO}_{2}, \mathrm{NO}, \mathrm{NO}_{2}, \mathrm{CO}_{2}\right)$ in the air and a weather station provided wind, precipitation, solar radiation data and other quantities. Together with ship information for each vessel obtained from Automatic Identification System (AIS) broadcasts a detailed characterization of the individual ship types and of features affecting gas and particulate emissions is provided.

Particle number EFs (average $2.6 e+16 \# \mathrm{~kg}^{-1}$ ) and $\mathrm{PM}_{1}$ mass EFs (average $2.4 \mathrm{~g} \mathrm{~kg}^{-1}$ ) tend to increase with the fuel sulfur content. Observed $\mathrm{PM}_{1}$ composition of the vessel emissions was dominated by organic matter $(72 \%)$, sulfate $(22 \%)$ and black carbon $(6 \%)$ while PAHs only account for $0.2 \%$ of the submicron aerosol mass. Measurements of
\end{abstract}

gaseous components showed an increase of $\mathrm{SO}_{2}$ (average EF: $7.7 \mathrm{~g} \mathrm{~kg}^{-1}$ ) and $\mathrm{NO}_{\mathrm{x}}$ (average EF: $53 \mathrm{~g} \mathrm{~kg}^{-1}$ ) while $\mathrm{O}_{3}$ decreased when a ship plume reached the sampling site. The particle number size distributions of the vessels are generally characterized by a bimodal size distribution, with the nucleation mode in the 10-20 $\mathrm{nm}$ diameter range and a combustion aerosol mode centered at about $35 \mathrm{~nm}$ while particles $>1 \mu \mathrm{m}$ were not found. "High particle number emitters" are characterized by a dominant nucleation mode. By contrast, increased particle concentrations around $150 \mathrm{~nm}$ primarily occurred for "high black carbon emitters". Classifying the vessels according to their gross tonnage shows a decrease of the number, black carbon and PAH EFs while EFs of $\mathrm{SO}_{2}, \mathrm{NO}$, $\mathrm{NO}_{2}, \mathrm{NO}_{\mathrm{x}}$, AMS species (particulate organics, sulfate) and $\mathrm{PM}_{1}$ mass concentration increase with increasing gross tonnages.

\section{Introduction}

Gaseous and particulate emissions from marine vessels gain increasing attention due to their significant contribution to the anthropogenic burden of the atmosphere, the change of the atmospheric composition and the impact on local and regional air quality and climate (Corbett and Fischbeck, 1997; Endresen et al., 2003; Eyring et al., 2005a, 2010). Increased $\mathrm{NO}_{\mathrm{x}}$ levels caused by ship emissions can be seen along the shipping routes via satellite measurements (Beirle et al., 2004). In addition, these emissions have a significant impact on the ozone chemistry and increase hydroxyl radical 
concentrations thereby having an influence on the oxidation power of the atmosphere (Lawrence and Crutzen, 1999). Ship emission-related black carbon, a major light-absorbing species and sulfuric acid, an efficient light-scattering species, both formed during combustion processes are suggested to have an important impact on the earth's radiation budget (Endresen et al., 2003; Petzold et al., 2008; Eyring et al., 2010). Cloud condensation nuclei (CCN) in ship exhaust indirectly affect global radiative forcing, visible in satellite images as so-called "ship tracks", regions downwind of ships characterized by increased solar reflectivity due to marine stratiform clouds (Hobbs et al., 2000; Durkee et al., 2000; Dusek et al., 2006).

Due to the large variety of impacts a broad interest exists in emissions from marine vessels. However, only sparse literature is available on the large range of ship emissions that depend on engine type and technology, operation conditions and the different kinds of fuel types. The available experimental studies can be separated in:

- Laboratory engine studies (Lyyranen et al., 1999; Kasper et al., 2007; Sarvi et al., 2008).

- On-board studies performed on a ship in operation (Cooper, 2001; Agrawal et al., 2008; Fridell et al., 2008; Moldanova et al., 2009).

- Studies tracking individual ship emission plumes by using aircrafts or ships (Hobbs et al., 2000; Osborne et al., 2001; Sinha et al., 2003; Chen et al., 2005; Petzold et al., 2008; Lack et al., 2009; Murphy et al., 2009; Williams et al., 2009; Moldanova et al., 2009).

- Stationary measurements affected by ship plumes (e.g. harbors) (Lu et al., 2006; Agrawal et al., 2009; Healy et al., 2009; Ault et al., 2010; Jonsson et al., 2011).

Since a significant fraction of the emissions even from ocean-going vessels occurs close to land, such emissions may have a strong impact on air quality in coastal and port regions (Corbett et al., 1999). For this reason, global regulations exist to restrict commercial marine vessel emissions (IMO, 2009). Additionally, so-called emission control areas (ECA) have been defined to reduce local and regional shiprelated pollution. Having a potentially important role as air pollutant and on climate an improved understanding of the emissions, a detailed characterization of the chemical composition and processing of particles and their dependence on characteristic vessel parameters is desirable. However, literature is only sparse as recently summarized in Jonsson et al. (2011).

In this study, highly time-resolved stationary measurements of air pollutants were performed on the banks of the Lower Elbe which is passed by a large number of oceangoing vessels of different types entering and leaving the port of Hamburg. Using a mobile laboratory, chemical and physical aerosol properties as well as trace gas properties of ship emissions were characterized in this ECA next to populated areas. Emission factors (EFs) were determined for individual vessels for particle number and black carbon, polycyclic aromatic hydrocarbons and chemical $\mathrm{PM}_{1}$ species as well as the trace gases sulfur dioxide and nitrogen oxides. In addition particle size distributions were measured for each ship separately. By using ship information data gathered via Automated Identification System (AIS) broadcasts, we are able to extract vessel characteristics that affect gas and particulate emissions. The number of vessels sampled allows the categorization of ships into different types and the identification of relationships between EFs and ship properties.

\section{Experimental methods}

\subsection{Measurement campaign}

The ship emission measurement campaign was conducted near the Elbe river mouth in Northern Germany (Fig. 1a) between 25 and 29 April 2011. 178 commercial and private vessels were probed during the 5 days of sampling, with 139 of the measured ship plumes being of sufficient quality to be considered in the analysis. The remaining ships could not be evaluated because plumes overlapped, e.g. when vessels from both directions pass the Elbe and their plumes reach the measurement site at the same time. The measurement sites (25 April 2011: 53 $50^{\prime} 22^{\prime \prime} \mathrm{N}, 9^{\circ} 18^{\prime} 12^{\prime \prime} \mathrm{E}$; 26 April 2011 and 27 April 2001: 53 50 $50^{\prime} 47^{\prime \prime}$ N, 9 $9^{\circ} 17^{\prime} 16^{\prime \prime} \mathrm{E}$; 28 April 2011 and 29 April 2011: 53 $44^{\prime} 17^{\prime \prime}$ N, $9^{\circ} 24^{\prime} 0^{\prime \prime}$ E; Fig. 1b) were located near Freiburg/Elbe between Cuxhaven and Hamburg on the banks of the Elbe, chosen to be located directly downwind of the ship tracks. As the wind directions during the study period varied between N-NO (see trajectories in Fig. 1a) three different measurement sites were chosen to prevent local pollution to interfere with the ship plumes. During the study relatively clean air from the Baltic and North Sea was transported to the measurement sites. The Elbe is daily passed by numerous ocean-going vessels entering and leaving the port of Hamburg, the second largest freight port of Europe. The measurements were conducted in an emission control area (ECA) where the ship fuel sulfur content is legally fixed not to exceed $1 \%$ by weight since 1 July 2010 . At the measurement sites, the Elbe is about $2 \mathrm{~km}$ wide. For this reason most vessels were probed and identified at a distance of about 0.8 and $1.2 \mathrm{~km}$, reflecting the main shipping lanes (upstream/downstream the Elbe). During the 5 days of sampling similar meteorological conditions existed (no rain, similar temperatures, RH) with an average wind speed of $6 \mathrm{~m} \mathrm{~s}^{-1}$. The plumes were measured directly downwind the Elbe. For this reason, dependent on the meteorological situation and the distance between ship and sampling site the ages of the registered plumes vary between $1-5 \mathrm{~min}$. 


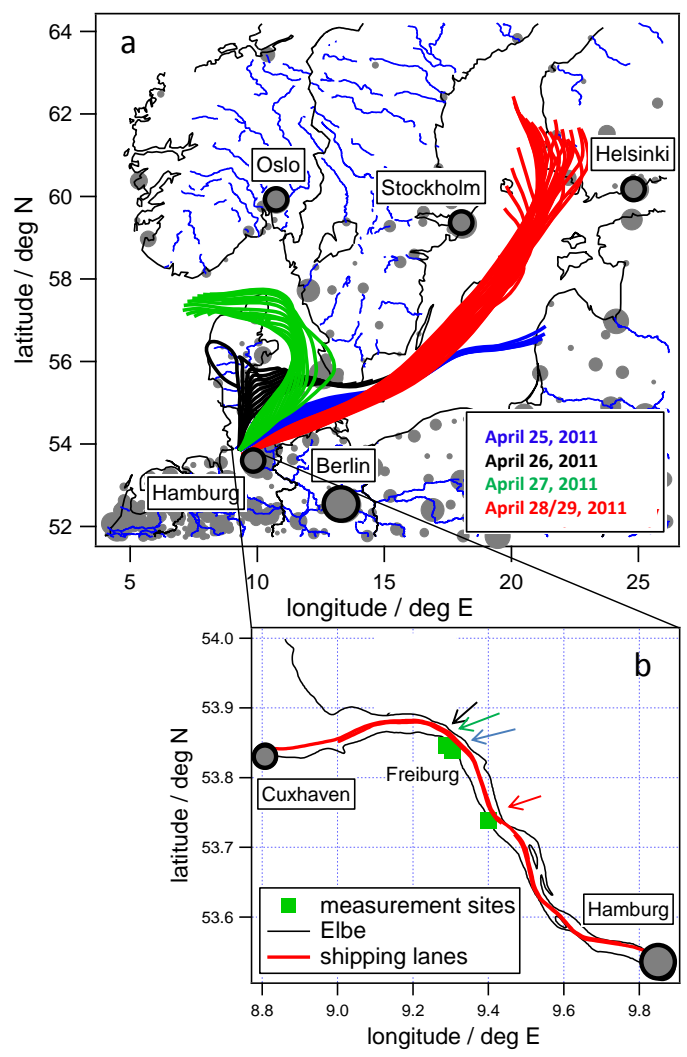

Fig. 1. Map showing the location of the measurement sites including $48 \mathrm{~h}$ backwards trajectories calculated for every hour and each measurement day using HYSPLIT (a). As the wind direction range was N-NO, the measurement sites were located downwind the Elbe. The zoom-in at the lower right shows the positions of the measurement sites (green squares), the measured local wind directions at each site, and the shipping lanes on the Elbe (b).

\subsection{Instrumentation}

During the campaign, a comprehensive set of aerosol and trace gas instruments was used, implemented in the mobile laboratory MoLa, a mobile platform for aerosol research (see Table 1). This included an ultrafine water-based Condensation Particle Counter (CPC 3786, TSI, Inc., $2.5 \mathrm{~nm}-$ $3 \mu \mathrm{m})$ for particle number concentration measurement and an Environmental Dust Monitor (EDM 180, Grimm) measuring $\mathrm{PM}_{1}, \mathrm{PM}_{2.5}$ and $\mathrm{PM}_{10}$. Size distributions in the size range from $6 \mathrm{~nm}$ until $32 \mu \mathrm{m}$ were measured using a Fast Mobility Particle Sizer (FMPS 3091, TSI, Inc., $d_{\mathrm{mob}}=6$ $523 \mathrm{~nm}$ ), an Aerodynamic Particle Sizer (APS 3321, TSI, Inc., $\left.d_{\text {aero }}=0.37-20 \mu \mathrm{m}\right)$ as well as an Optical Particle Counter (OPC 1.109, Grimm, $d_{\text {opt }}=0.25-32 \mu \mathrm{m}$ ). Concentrations of non-refractory (NR) submicron aerosol species were detected by means of a High-Resolution Time-of-Flight Aerosol Mass Spectrometer (HR-ToF-AMS, Aerodyne Res., Inc.) using the medium mass resolution mode ("V-mode"). A Multi Angle Absorption Photometer (MAAP, Thermo
E.C.) registered black carbon concentrations in $\mathrm{PM}_{1}$ and polycyclic aromatic hydrocarbons on particles were measured by the PAH-Monitor (PAS 2000, EcoChem. Analytics, size range: $10 \mathrm{~nm}-1 \mu \mathrm{m})$. Additionally, for measuring various trace gases MoLa is equipped with the Airpointer (Recordum $\mathrm{GmbH}$ ) which monitors $\mathrm{SO}_{2}, \mathrm{CO}, \mathrm{NO}, \mathrm{NO}_{2}$ and $\mathrm{O}_{3}$ mixing ratios and the LICOR 840 gas analyzer (LI-COR, Inc.) that measures $\mathrm{CO}_{2}$. The WXT 510 weather station (Vaisala) provided meteorological quantities (ambient temperature, relative humidity, air pressure, wind speed, wind direction and rain intensity) - for further information see Drewnick et al. (2012).

During the ship plume measurements the roof inlet of MoLa was used which is designed for stationary measurements. Alongside the inlet line, an extendable mast with the meteorological station was fixed, both reaching a height of $7 \mathrm{~m}$ above ground level. In order to capture as many data points of the ship plumes as possible, high time resolution of the measurements is essential. Most instruments have a time resolution of $12 \mathrm{~s}$ or less, besides the AMS and MAAP instruments that measured in $1 \mathrm{~min}$ time intervals (Table 1). Since during the expected short plume intercepts no reasonable size distribution measurement with the AMS is possible and not to lose measurement time, the AMS was operated in MS mode only, measuring aerosol mass spectra without size information. Further information on the mobile platform for aerosol research (MoLa), its instrumentation and their time resolution can be found in Drewnick et al. (2012).

\subsection{Data quality assurance}

Although the sampling inlet of MoLa was optimized for minimal transport losses and sampling artifacts, characteristic particle losses for all instruments were estimated using the Particle Loss Calculator (von der Weiden et al., 2009). In the size range where the majority of data were measured particle losses are small (see Table 1). For this reason, the occurring particle losses were neglected as the measurement results were not significantly influenced and the ambient aerosol was measured widely unbiased.

Several AMS calibrations were conducted during the study. A calibration of the Ionization Efficiency (IE) of the ion source was performed before the beginning of the campaign and after its end. Several distinct instrument parameters and the instrument background were determined using measurements through a High-Efficiency Particulate Air (HEPA) filter. Every second day, the detector gain was calibrated. To account for particles that cannot be detected as they bounce off the vaporizer before evaporation or due to incomplete transmission through the AMS inlet system a Collection Efficiency (CE) factor has to be determined (Huffman et al., 2005). This CE factor was estimated by comparing the sum of the AMS species (organics, sulfate, nitrate, ammonium and chloride) concentrations and the MAAP black carbon mass concentrations with the EDM $\mathrm{PM}_{1}$ mass 
Table 1. Summary of measured quantities, size ranges and the corresponding particle losses, time resolution and detection limits for the instruments implemented in the mobile laboratory (MoLa). Particle losses within the given size range boundaries are lower than those provided here; therefore the given losses are upper limits.

\begin{tabular}{|c|c|c|c|c|}
\hline $\begin{array}{l}\text { Measurement } \\
\text { Instrument }\end{array}$ & Measured Quantity & $\begin{array}{l}\text { Size Range/ } \\
\text { (Particle losses) }\end{array}$ & $\begin{array}{l}\text { Time } \\
\text { resolution }\end{array}$ & Detection Limits/Accuracy \\
\hline $\begin{array}{l}\text { AMS Aerosol Mass } \\
\text { Spectrometer }\end{array}$ & $\begin{array}{l}\text { Size-resolved aerosol } \\
\text { chemical composition }\end{array}$ & $\begin{array}{l}40 \mathrm{~nm}(6 \%)- \\
600 \mathrm{~nm}(2 \%) \\
\text { (vacuum aerodynamic } \\
\text { diameter) }\end{array}$ & $1 \mathrm{~min}$ & $\begin{array}{l}\text { sulfate: } 0.04 \mu \mathrm{g} \mathrm{m}^{-3} \\
\text { nitrate: } 0.02 \mu \mathrm{g} \mathrm{m}^{-3} \\
\text { ammonium: } 0.05 \mu \mathrm{g} \mathrm{m}^{-3} \\
\text { chloride: } 0.02 \mu \mathrm{g} \mathrm{m}^{-3} \\
\text { organics: } 0.09 \mu \mathrm{g} \mathrm{m}^{-3}\end{array}$ \\
\hline $\begin{array}{l}\text { MAAP Multi Angle } \\
\text { Absorption Photometer }\end{array}$ & $\begin{array}{l}\text { Black carbon particle } \\
\text { mass concentration }\end{array}$ & $\begin{array}{l}10 \mathrm{~nm}(4 \%)- \\
1 \mu \mathrm{m}(0.2 \%)\end{array}$ & $1 \mathrm{~min}$ & $0.1 \mu \mathrm{g} \mathrm{m}^{-3}$ \\
\hline $\begin{array}{l}\text { PAH-Sensor } \\
\text { Polycyclic Aromatic } \\
\text { Hydrocarbons Sensor }\end{array}$ & $\begin{array}{l}\text { Total PAH mass } \\
\text { concentration }\end{array}$ & $\begin{array}{l}10 \mathrm{~nm}(11 \%)- \\
1 \mu \mathrm{m}(0.3 \%)\end{array}$ & $12 \mathrm{~s}$ & $1 \mathrm{ng} \mathrm{m}^{-3}$ \\
\hline $\begin{array}{l}\text { CPC Condensation } \\
\text { Particle Counter }\end{array}$ & $\begin{array}{l}\text { Particle number } \\
\text { concentration }\end{array}$ & $\begin{array}{l}2.5 \mathrm{~nm}(15 \%)- \\
3 \mu \mathrm{m}(0.8)\end{array}$ & $1 \mathrm{~s}$ & N/A \\
\hline $\begin{array}{l}\text { EDM Environmental } \\
\text { Dust Monitor }\end{array}$ & $\begin{array}{l}\text { Particle mass } \\
\text { concentration } \\
\left(\mathrm{PM}_{1 ; 2.5 ; 10}\right)\end{array}$ & $\begin{array}{l}0.25 \mu \mathrm{m}(0.2 \%)- \\
10 \mu \mathrm{m}(24 \%)\end{array}$ & $6 \mathrm{~s}$ & $\begin{array}{l}0.1-1500 \mu \mathrm{g} \mathrm{m}^{-3}, \\
\text { ducibility: } 5 \%\end{array}$ \\
\hline $\begin{array}{l}\text { FMPS Fast Mobility } \\
\text { Particle Sizer }\end{array}$ & $\begin{array}{l}\text { Particle size distribu- } \\
\text { tion based on electrical } \\
\text { mobility }\end{array}$ & $\begin{array}{l}6 \mathrm{~nm}(9 \%)- \\
523 \mathrm{~nm}(0.1 \%) \\
\left(D_{\mathrm{mob}}\right)\end{array}$ & $1 \mathrm{~s}$ & N/A \\
\hline $\begin{array}{l}\text { APS Aerodynamic Par- } \\
\text { ticle Sizer }\end{array}$ & $\begin{array}{l}\text { Particle size distribu- } \\
\text { tion based on aerody- } \\
\text { namic sizing }\end{array}$ & $\begin{array}{l}0.37 \mu \mathrm{m}(0.1 \%)- \\
20 \mu \mathrm{m}(45 \%) \\
\left(D_{\text {aero }}\right)\end{array}$ & $1 \mathrm{~s}$ & N/A \\
\hline $\begin{array}{l}\text { OPC Optical Particle } \\
\text { Counter }\end{array}$ & $\begin{array}{l}\text { Particle size distribu- } \\
\text { tion based on light } \\
\text { scattering cross } \\
\text { section }\end{array}$ & $\begin{array}{l}0.25 \mu \mathrm{m}(0.05 \%)- \\
32 \mu \mathrm{m}(0.002 \%) \\
\left(D_{\text {opt }}\right)\end{array}$ & $6 \mathrm{~s}$ & N/A \\
\hline Airpointer & $\begin{array}{l}\mathrm{O}_{3}, \mathrm{SO}_{2}, \mathrm{CO} \text { and } \mathrm{NO}, \\
\mathrm{NO}_{2} \text { mixing ratio }\end{array}$ & N/A & $\begin{array}{l}4 \mathrm{~s} \\
\mathrm{NO}_{\mathrm{x}}: 8 \mathrm{~s}\end{array}$ & $\begin{array}{l}\mathrm{O}_{3}:<1.0 \mathrm{nmol} \mathrm{mol}^{-1} \\
\mathrm{SO}_{2}:<1.0 \mathrm{nmol} \mathrm{mol}^{-1} \\
\mathrm{CO}:<0.08 \mu \mathrm{mol} \mathrm{mol}^{-1} \\
\mathrm{NO}_{\mathrm{X}}:<2.0 \mathrm{nmol} \mathrm{mol}^{-1}\end{array}$ \\
\hline LICOR LI840 & $\begin{array}{l}\mathrm{CO}_{2} \text { and } \mathrm{H}_{2} \mathrm{O} \text { mixing } \\
\text { ratio }\end{array}$ & N/A & $1 \mathrm{~s}$ & 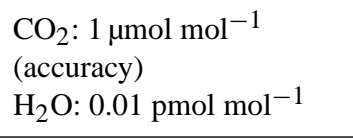 \\
\hline Met. Station & $\begin{array}{l}\text { Wind speed \& direction } \\
\text { temperature, } \mathrm{RH} \text {, rain } \\
\text { intensity, pressure }\end{array}$ & N/A & $1 \mathrm{~s}$ & N/A \\
\hline
\end{tabular}

concentrations. When using the typical CE factor of 0.5 for the AMS measurements a satisfying mass closure was generally found. However, occasionally the AMS plus MAAP specified aerosol concentrations are lower than the EDM $\mathrm{PM}_{1}$ mass concentrations. This difference is likely due to sea salt, which cannot be measured with the AMS with high efficiency.

\subsection{Analysis of plume events to determine emission factors}

For an objective and more efficient handling of the comprehensive data set of chemical, physical and gas phase characteristics from 139 individual ship exhaust plumes, a data analysis tool (Fig. 2) was custom-programmed. The analysis tool supports the characterization of the ship emissions as it calculates emission factors for each ship and measured 


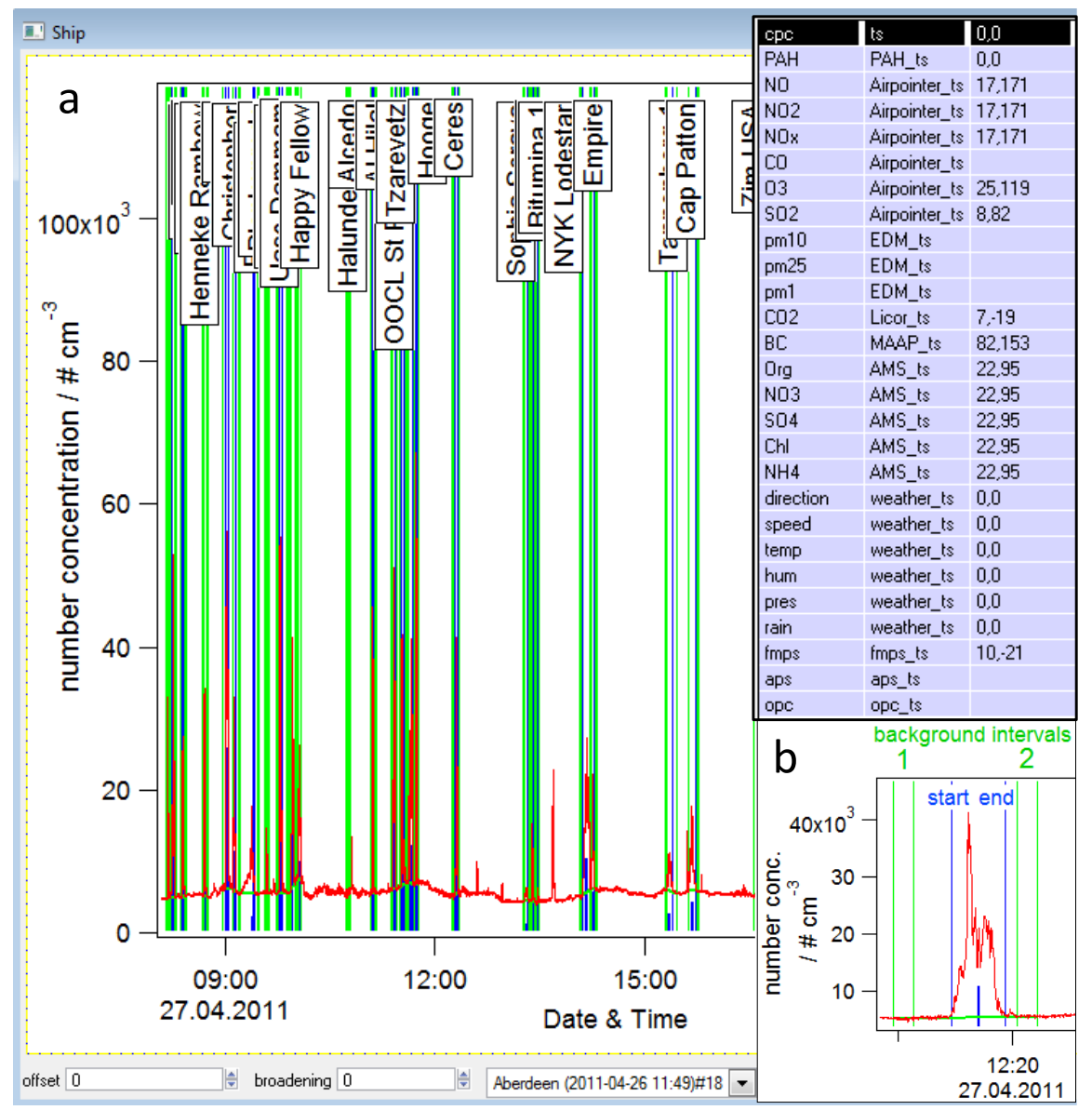

Fig. 2. Cutout of the ship analysis tool which calculates emission factors for each ship and measured quantity showing particle number concentration (CPC) time series (a). Emission factors were calculated using manually selected start and end points in the number concentration time series for each ship plume (b). For the other quantities a constant delay and broadening (a, third column of the table on the right) with respect to the number concentration measurement was applied for calculating the average concentrations. The background was subtracted by using a linear fit between the background intervals 1 before and 2 after the ship plume, both hand-selected for each plume and quantity (b).

quantity using the $\mathrm{CO}_{2}$ balance method which assumes that all of the carbon in the fuel is emitted as $\mathrm{CO}_{2}$ (Hobbs et al., 2000). Therefore, this approach of calculating emission factors of the pollutants accounts for dilution of the exhaust plume.

The emission factor of the species $\mathrm{x}\left(\mathrm{EF}_{\mathrm{x}}\right)$ is provided in grams or number of $\mathrm{x}$ emitted per kilogram of fuel burned $\left(\mathrm{g} \mathrm{kg}^{-1}\right.$ or $\left.\# \mathrm{~kg}^{-1}\right)$. It is defined as the ratio between the average excess concentration of species $\mathrm{x}(\Delta \mathrm{x})$ in $\mu \mathrm{g} \mathrm{m}^{-3}(1)$ or $\# \mathrm{~cm}^{-3}(2)$ in the measured emission plume above the ambient background level and the average excess $\mathrm{CO}_{2}$ concentration $\left(\Delta \mathrm{CO}_{2}\right)$ in $\mathrm{mg} \mathrm{m}^{-3}$. In addition, the ratios of molar masses of $\mathrm{CO}_{2}\left(44 \mathrm{~g} \mathrm{~mol}^{-1}\right)$ and carbon $\left(12 \mathrm{~g} \mathrm{~mol}^{-1}\right)$ convert the $\mathrm{CO}_{2}$ to carbon concentrations. The mass fraction of carbon in marine diesel fuel is $w_{\mathrm{c}}=0.865$ (Lloyd's Register, 1995). Thus, the emission factor in grams of a certain species per kg fuel burned is:

$$
\mathrm{EF}_{\mathrm{x}}\left(\mathrm{g} \mathrm{kg}^{-1}\right)=\frac{\Delta \mathrm{x}\left(\mu \mathrm{g} \mathrm{m}^{-3}\right)}{\Delta \mathrm{CO}_{2}\left(\mathrm{mg} \mathrm{m}^{-3}\right) \cdot \frac{\mathrm{C}\left(\mathrm{g} \mathrm{mol}^{-1}\right)}{\mathrm{CO}_{2}\left(\mathrm{~g} \mathrm{~mol}^{-1}\right)}} \cdot w_{\mathrm{c}}
$$

The uncertainties of the emission factors were calculated by means of Gaussian error propagation as follows: $\sqrt{(\sigma(\Delta \mathrm{x}))^{2}+\left(\sigma\left(\Delta \mathrm{CO}_{2}\right)\right)^{2}}$. Size-separated particle number emission factors $\left(\mathrm{dEF}_{\mathrm{N}} / \mathrm{d} \log D_{\mathrm{p}}\right)$ were determined by using Eq. (2) for each of the particle size bins individually:

$$
\mathrm{EF}_{\mathrm{x}}\left(\# \mathrm{~kg}^{-1}\right)=\frac{\Delta \mathrm{x}\left(\# \mathrm{~cm}^{-3}\right)}{\Delta \mathrm{CO}_{2}\left(\mathrm{mg} \mathrm{m}^{-3}\right) \cdot \frac{\mathrm{C}\left(\mathrm{g} \mathrm{mol}^{-1}\right)}{\mathrm{CO}_{2}\left(\mathrm{~g} \mathrm{~mol}^{-1}\right)}} \cdot w_{\mathrm{c}} \cdot 10^{12}
$$

Determination of emission factors using the plume analysis tool

- Firstly, the average concentrations of all measured quantities of each ship plume were calculated. Dependent on the instrument, ship emissions were registered 
with different but constant delays and broadenings as shown in the time series in Fig. 3. These effects result from the transport times through the sampling line that slightly differ for the individual instruments and the internal measurement time constants of the instruments. Therefore, the sampling and the measurement times are not identical and this delay must be corrected for. As shown in Fig. 3, the number concentration was the first variable that quickly increased apparently without instrument-related delays and it was always enhanced when a ship passed the site. Therefore, the average number concentration of each ship plume was determined from the start until the end point of the associated peak, both defined manually (Fig. 2b, blue lines). These start and end points of each plume in the number concentration data were used as a reference to which the offset and broadening of all other quantities were referred to. The offsets and broadenings for each quantity were identified using several very distinct plume events and are shown in the third column of the table in Fig. 2a. Some measured quantities which did not exhibit an offset and broadening are explained in Sect. 3 .

- Secondly, the $\mathrm{CO}_{2}$ balance method implies the removal of the background from each ship plume and quantity individually to calculate the excess concentrations. The background concentrations of the measured aerosol and gas phase species were subtracted using a linear fit between the manually defined background intervals 1 and 2 (pre- and post-plume, green lines in Fig. $2 \mathrm{a}$ and b).

By referring the excess of the emitted species $\Delta \mathrm{x}$ to $\Delta \mathrm{CO}_{2}$ and therefore to the quantity of fuel used, plume dilution can be neglected under the assumption that the ratio of the emitted species $\mathrm{x}$ to $\mathrm{CO}_{2}$ is conserved during plume expansion. For this reason, we assume that the same dilution of $\mathrm{x}$ compared to the chemically inert tracer gas $\mathrm{CO}_{2}$ exists. This method is limited by all field measurements as transformation processes cannot be completely excluded. For nonconservable emissions, where quick particle coagulation, deposition and chemical processing occur downwind of the ship exhaust emissions Petzold et al. (2008) utilized the term "emission indices". However, according to Hinds (1999) coagulation processes of emissions after leaving the stack did not occur to any significant degree. For this reason and as we cannot identify which species are not conserved the term "emission factor" will be retained in this study. It should be noted that relatively fresh emission plumes were probed during this study. Dependent on the meteorological situation and the distance between ship and sampling site the ages of the registered plumes vary between $1-5 \mathrm{~min}$.

A further limitation of the method is that in addition to $\mathrm{CO}_{2}$, carbon is emitted as carbon monoxide (CO), methane $\left(\mathrm{CH}_{4}\right)$, non-methane organic compounds (NMOC) and particulate carbon (PC). A CO enhancement was not registered during any of the ship plume encounters. The occurrence of $\mathrm{CH}_{4}, \mathrm{NMOC}$ and $\mathrm{PC}$ is assumed to be relatively small. Therefore the assumption that most of the carbon is emitted as $\mathrm{CO}_{2}$ is a good approximation providing an upper limit for the EFs.

\subsection{Different types of ships studied and classification into vessel classes}

Ship information including ship name, commercial type, length, breadth, deepness, speed, position, gross tonnage and engine power was collected from Automated Identification System (AIS) broadcasts. AIS is a globally implemented identification system mandatory in all vessels larger than 20 $\mathrm{m}$ length or gross tonnage larger than 300 . Specific data of each vessel are broadcasted continuously and serve for the prevention of collisions between vessels. The system allows identification of the individual ships passing the measurement site and thus assigning the specific ship characteristics to each of the registered plumes and to classify the measured vessels into different types.

Using AIS, the vessels were separated into 7 types (container ships, tankers, ferries \& RoRos, cargo ships, reefer \& bulkcarriers, riverboats and others). However, the characteristics of the individual vessels (size, speed, gross tonnage and engine power) within each of the classified ship types differ strongly resulting in large variations of the emissions. By detailed analysis, we found the gross tonnage which is a measure for the ships volume to be the most distinct factor in grouping different kinds of vessels. For this reason, vessels were classified in

- "Type 1" vessels which exhibit gross tonnages less than 5000 ,

- "Type 2" vessels are characterized by gross tonnages from 5000 up to 30000 and

- "Type 3" vessels exhibit a gross tonnage level larger than 30000 .

Additionally, two vessel types were identified according to their particle number and black carbon EFs as follows (see Fig. 4):

- "high PN emitters" represent those vessels which correspond to the $10 \%$ highest particle number emitters (grey box) while

- "high BC emitters" are characterized being one of the $10 \%$ highest black carbon polluters (brown box).

Although only a limited number of ships for some of the vessel types were measured, the aim of this study to cover a spectrum of ship types and volumes for evaluating the associated dependencies in the emission factors was achieved. Within individual ship types a large range of ship volumes/lengths exists. For this reason, the gross tonnage is a key parameter for characterizing the variety of vessels. The 


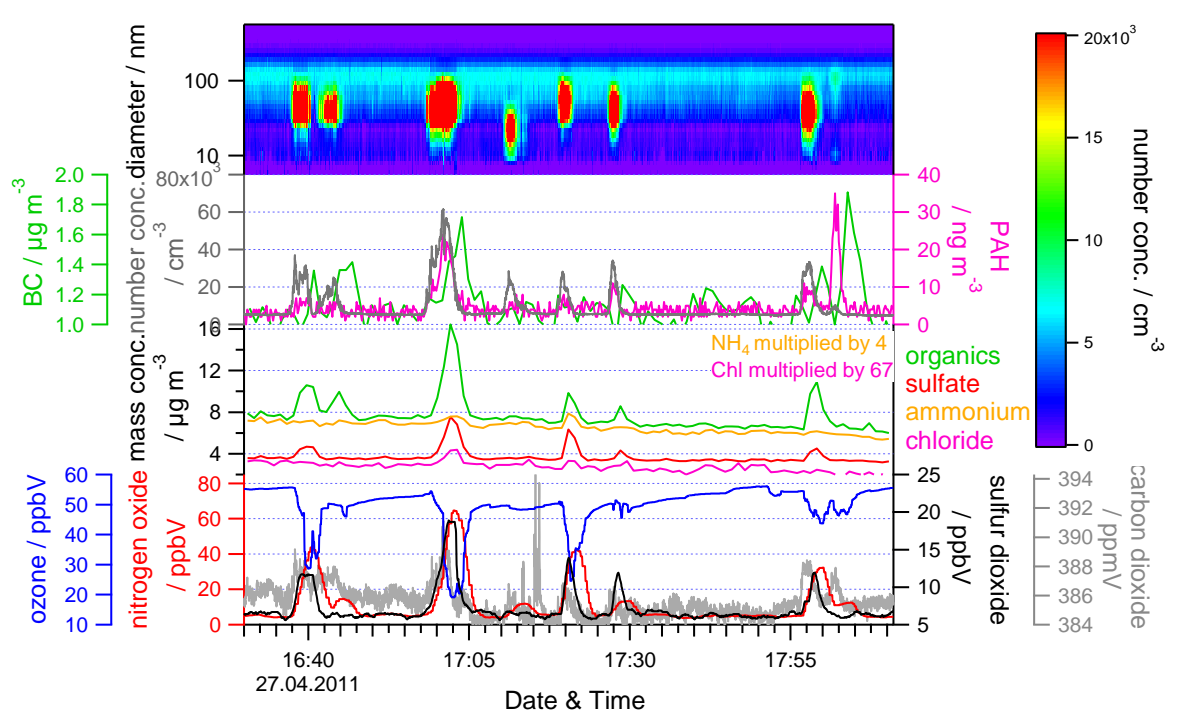

Fig. 3. Cutout of the time series for relevant concentrations showing 9 ship plumes. Here the third plume event consists of two different ship emission plumes which are overlapped and were therefore not further evaluated. Shown are aerosol measurements like the size-resolved and total number concentration (FMPS, CPC), black carbon (MAAP), PAH (PAS) and non-refractory species (AMS: organics, sulfate, ammonium, chloride) concentrations as well as gas phase measurements of $\mathrm{SO}_{2}, \mathrm{NO}_{\mathrm{x}}, \mathrm{CO}_{2}$ and $\mathrm{O}_{3}$ (Airpointer, Licor).

gross tonnage is a measure for the ships volume and depends on the ships length by a power function as also mentioned by Hulskotte and van der Gon (2010). The ships gross tonnage was found to be directly proportional to the engine power (Pearson correlation coefficient $R=0.97$ ). Within the available ship-related variables from the AIS data ship size (i.e. gross tonnage) and the related engine power were the variables that showed the clearest relationship with our measured emission factors. Indeed, ship size/gross tonnage and engine power are not the only crucial variables that determine the EFs. Engine type, the propulsion system and engine load are expected to play an important role as well. However, since these variables were not (or only for a small fraction of ships) available from the AIS data no relationship between the measured EFs and these variables could be investigated. Likely, the mixture of combinations in engine and propulsion type and engine load within the probed vessels leads to additional scatter in the data, indicated in the figures by the partly large error bars.

\section{Results}

\subsection{Identification of plume-related species}

The ship plumes registered by MoLa can be identified as more or less pronounced peaks in the time series of several variables (Fig. 3). Those measured quantities for which a significant enhancement over the background level was observed when a ship passed the site were considered in the further analysis. For this reason, as for every quantity the Limit

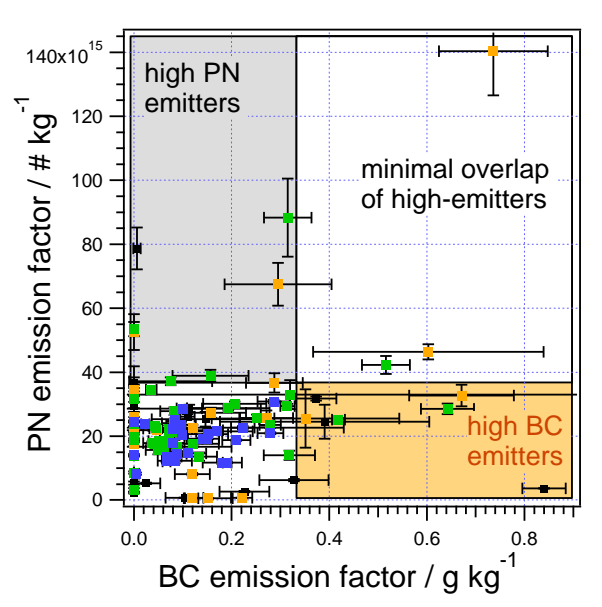

Fig. 4. Scatter plot of particle number versus black carbon emission factors for the individual vessel types ("Type 1": orange, "Type 2": green, "Type 3": blue). While the grey box highlights the highest $10 \%$ of PN emitters, the brown one reflects the $10 \%$ highest $\mathrm{BC}$ emitters. Only a small overlap (3 vessels) exists with high-emitters of both pollutants which were therefore not considered in the analysis. High PN or BC emitters are among the smaller vessels. Markers which represent gross tonnage values larger than 30000 (blue) show a proportionality of PN and BC EFs. Some vessels are black-coded as no gross tonnage values exist for vessels smaller than $20 \mathrm{~m}$ length or gross tonnage values below 300 . Error bars were determined by means of Gaussian error propagation.

of Detection (LOD) is different (see Table 1) the number of ships for which EFs could be determined varies. The cutout of the time series (Fig. 3) shows 9 ship plumes. An individual 
plume lasted for about $5 \mathrm{~min}$, dependent on the characteristic broadening of each quantity that was caused by the different instrumental time constants. For the third event in the depicted time series two plumes were registered simultaneously. Therefore they cannot be separated and further evaluated. Additionally, the signals are not perfectly synchronous in time as the aerosol transport times through the sampling line slightly differ for the individual instruments.

Figure 3 shows several typical characteristics of the measured plumes. In the top panel the size-resolved particle number concentrations are displayed showing dominant modes in the $10-120 \mathrm{~nm}$ size range when ship exhaust was sampled. A sharp increase was also observed in the total number, black carbon, $\mathrm{PAH}, \mathrm{SO}_{2}, \mathrm{NO}_{\mathrm{x}}, \mathrm{CO}_{2}$ and the particulate organic and sulfate mass concentrations which are directly affected by ship engine exhaust. In addition, apparently some of the emitted species indirectly affect particulate ammonium and chloride which were observed to increase in several of the plumes. Finally, $\mathrm{O}_{3}$ was indirectly affected which often rapidly decreases from background concentrations at the plume onset due to reaction of ozone with $\mathrm{NO}$ forming $\mathrm{NO}_{2}$ (Lawrence and Crutzen, 1999).

No significant increase compared to the background levels was found in the particle size distributions of the APS and OPC. Apparently the impact of the ship plumes on the aerosol in the size range larger than $250 \mathrm{~nm}$ is either very small or simply not reflected in the data due to the poor counting statistics in this particle size range. This is likely also the reason for the fact that no enhancement in the $\mathrm{PM}_{2.5}$ and $\mathrm{PM}_{10}$ was observed due to the ship emissions. EDM PM instead did not increase when a ship passed the site as particles smaller $250 \mathrm{~nm}$ cannot be measured by this instrument but were determined by approximation based on size distributions in the $250 \mathrm{~nm}-32 \mu \mathrm{m}$ size range. Finally, for CO no significant variations due to the plume were observed, reflecting very small $\mathrm{CO}$ concentrations within the emissions.

\subsection{Characterization of emissions}

In this section the typical emission factors (EFs) for the measured variables and particle size distributions for all measured vessels are presented while a detailed characterization for separated types of vessels is discussed in the next section. The EFs (in terms of quantities emitted per kg of fuel burned) of all quantities averaged for all vessel plumes measured during the campaign are summarized in Table 2 . An overview of the correlations between EFs and vessel characteristics together with the Pearson correlation coefficients $(R)$ are listed in Table 3. Although the obtained correlation coefficients are partially low, trends observed within this study for the quantities are visible and depend on a variety of factors which will be discussed.

Particle number EFs: all vessel plumes were found to contain particles in the 10-250 nm size range (Fig. 7). However, large differences of the particle number EFs between the individual vessels were observed $\left(\mathrm{EF}_{\min }=5.7 e+14 \# \mathrm{~kg}^{-1}\right.$, $\mathrm{EF}_{\max }=1.4 e+17 \mathrm{~kg}^{-1}$; see Fig. 4). The emitted particle number concentrations mainly depend on the kind of fuel the vessels used. As sulfuric acid is known to be an efficient particle nucleation precursor (Schneider et al., 2005), the sulfur content in fuel is a key variable influencing the particle number emissions. The average particle number $\mathrm{EF}$ for all vessels encountered is $2.6 e+16 \pm 1.9 e+16 \# \mathrm{~kg}^{-1}$ (Table 2).

Black carbon EFs: a completely different relationship to the vessel characteristics was observed for black carbon (BC) EFs. While also a large range of $\mathrm{BC}$ emissions $\left(\mathrm{EF}_{\min }<\mathrm{LOD}, \mathrm{EF}_{\max }=0.84 \mathrm{~g} \mathrm{~kg}^{-1}\right.$; see Fig. 4) were measured for various ships, generally $\mathrm{BC}$ values increased with decreasing vessel speed. A lower vessel speed is potentially associated with a less complete combustion process for which reason BC is formed. Therefore, we assume BC EFs depend mainly on the operating conditions of the engine. The average $\mathrm{BC}$ EF determined for all vessels in this study is $0.15 \pm 0.17 \mathrm{~g} \mathrm{~kg}^{-1}$ (Table 2).

Figure 4 shows a scatter plot of particle number and BC EFs for all ships probed during this study. The grey box highlights the $10 \%$ highest particle number emitters (10 vessels as EFs of 99 ship emission plumes could be calculated for both, PN and $\mathrm{BC}$ emitters), the brown box highlights the $10 \%$ highest $\mathrm{BC}$ emitters (10 vessels). While the highest $10 \%$ of PN emitters account for $23 \%$ of the total average particle number EF, the highest $10 \%$ of BC emitters cover $37 \%$ of the total black carbon EF. Only a minimal overlap among the two types of high-emitters exists - three vessels are characterized by both, high particle number as well as high BC EFs. The lack of overlap can be explained by the different processes leading to high particle number or high BC emissions: new particle formation is less favored when high black carbon concentrations exist as the larger surface area causes loss of condensable species onto pre-existing particles. Therefore, high black carbon emissions suppress new particle formation by scavenging freshly formed particles and absorbing condensable vapors resulting in lower particle number concentrations - and vice versa (Kerminen et al., 2001). However, considering all vessel plumes particle number EFs tend to increase with increasing $\mathrm{BC} E F s\left(\mathrm{EF}_{\mathrm{CPC}}\right.$ $\left(\mathrm{BC}\left[\mathrm{g} \mathrm{kg}^{-1}\right]\right)\left[\# \mathrm{~kg}^{-1}\right]=1.9 e+16+3.4 e+16 \cdot \mathrm{BC}\left[\mathrm{g} \mathrm{kg}^{-1}\right]$, $R=0.32$ ) likely because generally a more incomplete combustion process leads to higher particulate as well as BC emissions.

Sulfur dioxide EFs: $\mathrm{SO}_{2}$ emissions depend on the sulfur content of fuel burned and therefore on the type of fuel used. A higher fuel quality requires lower fuel sulfur content resulting in reduced $\mathrm{SO}_{2}$ emissions. From the average $\mathrm{SO}_{2} \mathrm{EF}$ of $7.7 \pm 6.7 \mathrm{~g} \mathrm{~kg}^{-1}$ (Table 2) and the $\mathrm{SO}_{4} \mathrm{EF}$ $\left(0.54 \pm 0.46 \mathrm{~g} \mathrm{~kg}^{-1}\right)$, the sulfur content in fuel can be calculated as follows: 
Table 2. Overview of ship characteristics and Emission Factors (EFs) for the different types of vessels investigated in this study. Averaged ship data from the AIS system (speed, gross tonnage $\left(1 \mathrm{GT} \approx 3.57 \mathrm{~m}^{3}\right)$, volume, length, engine power), observed mode maximum, sulfur (S) by weight in fuel and EFs (in \# per kg fuel or g per kg fuel) are tabulated. * Sulfur by weight in fuel was calculated as described in Sect. 3.2 .

\begin{tabular}{|c|c|c|c|c|c|c|}
\hline & $\begin{array}{l}\text { Type } 1 \text { ( } 39 \text { vessels) } \\
<5000 \text { tons }\end{array}$ & $\begin{array}{l}\text { Type } 2(59 \text { vessels }) \\
5000-30000 \text { tons }\end{array}$ & $\begin{array}{l}\text { Type } 3 \text { ( } 41 \text { vessels) } \\
>30000 \text { tons }\end{array}$ & high PN (7 vessels) & high BC (7 vessels) & all plumes (139 vessels) \\
\hline speed/knots & $13 \pm 6$ & $14 \pm 3$ & $13 \pm 2$ & $14 \pm 3$ & $9.1 \pm 3$ & $13 \pm 4$ \\
\hline gross tonnage & $2051 \pm 1205$ & $13983 \pm 6189$ & $70190 \pm 29816$ & $6925 \pm 4884$ & $9618 \pm 8037$ & $27214 \pm 32813$ \\
\hline volume $/ \mathrm{m}^{3}$ & $4580 \pm 3163$ & $32178 \pm 13935$ & $124000 \pm 45000$ & $13984 \pm 11024$ & $15266 \pm 16470$ & $42632 \pm 53341$ \\
\hline length/m & $80 \pm 22$ & $158 \pm 26$ & $286 \pm 49$ & $121 \pm 30$ & $101 \pm 52$ & $153 \pm 88$ \\
\hline engine power/kW & $2738 \pm 2251$ & $11055 \pm 5238$ & $39064 \pm 23033$ & $6608 \pm 4047$ & $6273 \pm 5167$ & $15545 \pm 18206$ \\
\hline mode maximum/nm & $28 \pm 16$ & $42 \pm 6.2$ & $44 \pm 6.6$ & $29 \pm 9$ & $26 \pm 12$ & $35 \pm 15$ \\
\hline sulfur (S) by weight in fuel*/\% & $0.22 \pm 0.21$ & $0.46 \pm 0.40$ & $0.55 \pm 0.20$ & $0.51 \pm 0.34$ & $0.30 \pm 0.23$ & $0.38 \pm 0.34$ \\
\hline particle number $\mathrm{EF} / \# \mathrm{~kg}^{-1}$ & $3.38 e+16 \pm 3.10 e+16$ & $2.64 e+16 \pm 1.48 e+15$ & $1.96 e+16 \pm 6.96 e+15$ & $5.95 e+16 \pm 1.94 e+16$ & $2.46 e+16 \pm 9.77 e+15$ & $2.55 e+16 \pm 1.91 e+16$ \\
\hline black carbon $\mathrm{EF} / \mathrm{g} \mathrm{kg}^{-1}$ & $0.21 \pm 0.23$ & $0.14 \pm 0.16$ & $0.12 \pm 0.08$ & $0.12 \pm 0.14$ & $0.53 \pm 0.19$ & $0.15 \pm 0.17$ \\
\hline nitrogen oxides $\left(\mathrm{NO}_{\mathrm{x}}\right) \mathrm{EF} / \mathrm{g} \mathrm{kg}^{-1}$ & $43 \pm 29$ & $57 \pm 28$ & $65 \pm 23$ & $57 \pm 23$ & $43 \pm 11$ & $53 \pm 27$ \\
\hline nitrogen monoxide (NO) $\mathrm{EF} / \mathrm{g} \mathrm{kg}^{-1}$ & $8.6 \pm 6.0$ & $18 \pm 12$ & $25 \pm 11$ & $12 \pm 3.5$ & $9 \pm 6$ & $16 \pm 12$ \\
\hline nitrogen dioxide $\left(\mathrm{NO}_{2}\right) \mathrm{EF} / \mathrm{g} \mathrm{kg}^{-1}$ & $35 \pm 25$ & $38 \pm 21$ & $40 \pm 17$ & $45 \pm 24$ & $34 \pm 7$ & $37 \pm 20$ \\
\hline $\mathrm{NO} / \mathrm{NO}_{2}$ & $0.31 \pm 0.29$ & $0.66 \pm 0.82$ & $0.67 \pm 0.32$ & $0.36 \pm 0.22$ & $0.27 \pm 0.18$ & $0.55 \pm 0.59$ \\
\hline sulfur dioxide $\left(\mathrm{SO}_{2}\right) \mathrm{EF} / \mathrm{g} \mathrm{kg}^{-1}$ & $4.5 \pm 4.1$ & $9.3 \pm 7.9$ & $11 \pm 4.0$ & $10 \pm 6.9$ & $5.9 \pm 4.5$ & $7.7 \pm 6.7$ \\
\hline sulfate $\left(\mathrm{SO}_{4}\right) \mathrm{EF} / \mathrm{g} \mathrm{kg}^{-1}$ & $0.28 \pm 0.38$ & $0.58 \pm 0.39$ & $0.92 \pm 0.39$ & $0.99 \pm 0.82$ & $0.20 \pm 0.28$ & $0.54 \pm 0.46$ \\
\hline organics (Org) EF/g kg-1 & $1.0 \pm 1.3$ & $2.1 \pm 1.9$ & $2.6 \pm 1.4$ & $2.8 \pm 2.2$ & $0.8 \pm 0.6$ & $1.8 \pm 1.7$ \\
\hline $\mathrm{PAHs} \mathrm{EF} / \mathrm{g} \mathrm{kg}^{-1}$ & $0.0080 \pm 0.0065$ & $0.0044 \pm 0.0030$ & $0.0034 \pm 0.0017$ & $0.0096 \pm 0.0036$ & $0.0074 \pm 0.0090$ & $0.0053 \pm 0.0047$ \\
\hline $\mathrm{PM}_{1\left(\mathrm{Org}+\mathrm{SO}_{4}+\mathrm{BC}\right)} \mathrm{EF} / \mathrm{g} \mathrm{kg}^{-1}$ & $1.6 \pm 1.7$ & $2.6 \pm 1.5$ & $3.7 \pm 1.7$ & $4.0 \pm 3.2$ & $1.5 \pm 1.1$ & $2.4 \pm 1.8$ \\
\hline
\end{tabular}

Table 3. Overview of the parameterizations of EF dependencies on vessel characteristics or dependencies between each other together with the Pearson correlation coefficients $(R)$ observed during this study.

\begin{tabular}{llll}
\hline correlations & \multicolumn{3}{c}{ coefficients } \\
\cline { 2 - 4 }$y=a+b x$ & $a$ & $b$ & $R$ \\
\hline $\mathrm{EF}_{\mathrm{CPC}}\left(\mathrm{BC}\left[\mathrm{g} \mathrm{kg}^{-1}\right]\right)\left[\# \mathrm{~kg}^{-1}\right]$ & $1.9 e+16$ & $3.4 e+16$ & 0.32 \\
$\mathrm{EF}_{\mathrm{CPC}}\left(\mathrm{EF}_{\left.\mathrm{SO}_{2}\left[\mathrm{~g} \mathrm{~kg}^{-1}\right]\right)\left[\# \mathrm{~kg}^{-1}\right]} 1.7 e+16\right.$ & $1.0 e+15$ & 0.41 \\
$\mathrm{EF}_{\mathrm{CPC}}(\operatorname{sulfur}[\%])\left[\# \mathrm{~kg}^{-1}\right]$ & $1.7 e+16$ & $2.0 e+16$ & 0.41 \\
$\mathrm{EF}_{\mathrm{PM}}(\operatorname{sulfur}[\%])\left[\mathrm{g} \mathrm{kg}^{-1}\right]$ & 0.19 & 6.1 & 0.80 \\
$\mathrm{EF}_{\mathrm{PAH}}\left(\mathrm{EF}_{\mathrm{BC}}[\mathrm{g} \mathrm{kg}-1]\right)\left[\mathrm{g} \mathrm{kg}^{-1}\right]$ & 0.003 & 0.02 & 0.57 \\
$\mathrm{EF}_{\mathrm{CPC}}\left(\mathrm{EF}_{\mathrm{PM}}[\mathrm{g} \mathrm{kg}-1]\right)\left[\# \mathrm{~kg}^{-1}\right]$ & $1.7 e+16$ & $3.0 e+15$ & 0.30 \\
$\mathrm{EF}_{\mathrm{Org}}(\operatorname{sulfur}[\%])\left[\mathrm{g} \mathrm{kg}^{-1}\right]$ & 0.06 & 4.4 & 0.85 \\
$\mathrm{EF}_{\mathrm{SO}_{4}}(\operatorname{sulfur}[\%])\left[\mathrm{g} \mathrm{kg}^{-1}\right]$ & 0.06 & 0.3 & 0.67 \\
\hline
\end{tabular}

$$
\begin{gathered}
\text { \% S by weight }=\left[\frac{\mathrm{EF}\left[\mathrm{SO}_{2}\left(\mathrm{~kg} \mathrm{~kg}^{-1}\right)\right]}{\mathrm{SO}_{2}\left(\mathrm{~g} \mathrm{~mol}^{-1}\right)} \cdot \mathrm{S}\left(\mathrm{g} \mathrm{mol}^{-1}\right)\right. \\
\left.+\frac{\mathrm{EF}\left[\mathrm{SO}_{4}\left(\mathrm{~kg} \mathrm{~kg}^{-1}\right)\right]}{\mathrm{SO}_{4}\left(\mathrm{~g} \mathrm{~mol}^{-1}\right)} \cdot \mathrm{S}\left(\mathrm{g} \mathrm{mol}^{-1}\right)\right] \cdot 100
\end{gathered}
$$

Typically in the measured plumes the first term which accounts for the $\mathrm{SO}_{2}$-related sulfur in the fuel contributes $95 \%$ of the total fuel sulfur content, as expected. In agreement with the marine fuel regulations in the North and Baltic Seas (ECA, MARPOL Annex VI, 2010) which requires vessels to burn low-sulfur fuel not to exceed $1 \%$ sulfur by weight, the average sulfur content in this study amounts to $0.4 \%$ averaged for all vessels (see Table 2). Two vessels did not stand on the rules and exhibit larger levels (see Fig. 5a). However, when considering the measurement uncertainties only one vessel exhibited slightly enhanced fuel sulfur contents.

As shown in Fig. 5a the particle number EFs tend to increase with increasing $\mathrm{SO}_{2} \mathrm{EFs}\left(\mathrm{EF}_{\mathrm{CPC}}\left(\mathrm{EF}_{\mathrm{SO}_{2}}\left[\mathrm{~g} \mathrm{~kg}^{-1}\right]\right)\right.$ $\left.\left[\# \mathrm{~kg}^{-1}\right]=1.7 e+16+1.0 e+15 \cdot \mathrm{EF}_{\mathrm{SO}_{2}}\left[\mathrm{~g} \mathrm{~kg}^{-1}\right], R=0.41\right)$, and thus with higher fuel sulfur contents $\left(\mathrm{EF}_{\mathrm{CPC}}\right.$ (sulfur[\%]) $\left[\# \mathrm{~kg}^{-1}\right]=1.7 e+16+2.0 e+16 \cdot$ sulfur[\%], $\left.R=0.41\right)$. This results likely from the oxidation of sulfur species in fuel to $\mathrm{SO}_{2}$ and $\mathrm{SO}_{3}$ which reacts to sulfuric acid $\left(\mathrm{H}_{2} \mathrm{SO}_{4}\right)$, the main precursor for new particle formation.

Nitrogen oxide EFs: in contrast to $\mathrm{SO}_{2}$, emission factors of $\mathrm{NO}_{\mathrm{x}}$ (average value: $53 \pm 27 \mathrm{~g} \mathrm{~kg}^{-1}$, see Table 2) apparently depend exclusively on the power of the ship engine. More powerful engines operating at higher temperatures emit more $\mathrm{NO}_{\mathrm{x}}$ (Sinha et al., 2003). As nitrogen oxide reacts with ozone $\left(\mathrm{O}_{3}\right)$ to $\mathrm{NO}_{2}$, the higher the $\mathrm{NO}$ concentrations emitted by the vessels, the lower the measured $\mathrm{O}_{3}$ concentrations. However, further downwind ozone precursors like hydrocarbons and $\mathrm{NO}_{\mathrm{x}}$ will form additional $\mathrm{O}_{3}$ photochemically.

Chemical particle composition: ship engine exhaust aerosol is composed of combustion particles consisting mainly of organic matter (OM), sulfate and black carbon (BC). Ash, a further exhaust component which was not registered during the campaign, accounts generally for a few percent to $\mathrm{PM}_{1}$ (Petzold et al., 2008). Additionally, in some plumes particulate ammonium and chloride were measured (see Fig. 3) possibly formed by reactions of exhaust species with pre-existing sea salt and ammonia in the air. However, most of the sulfate species in the plumes are existent as sulfuric acid making the submicron aerosol acidic. It should be noted that diesel engines are protected against corrosive exhaust gases by maintaining high gas flows and temperatures implying fuel sulfur is mainly emitted as $\mathrm{SO}_{2} . \mathrm{SO}_{3}$ and sulfur 

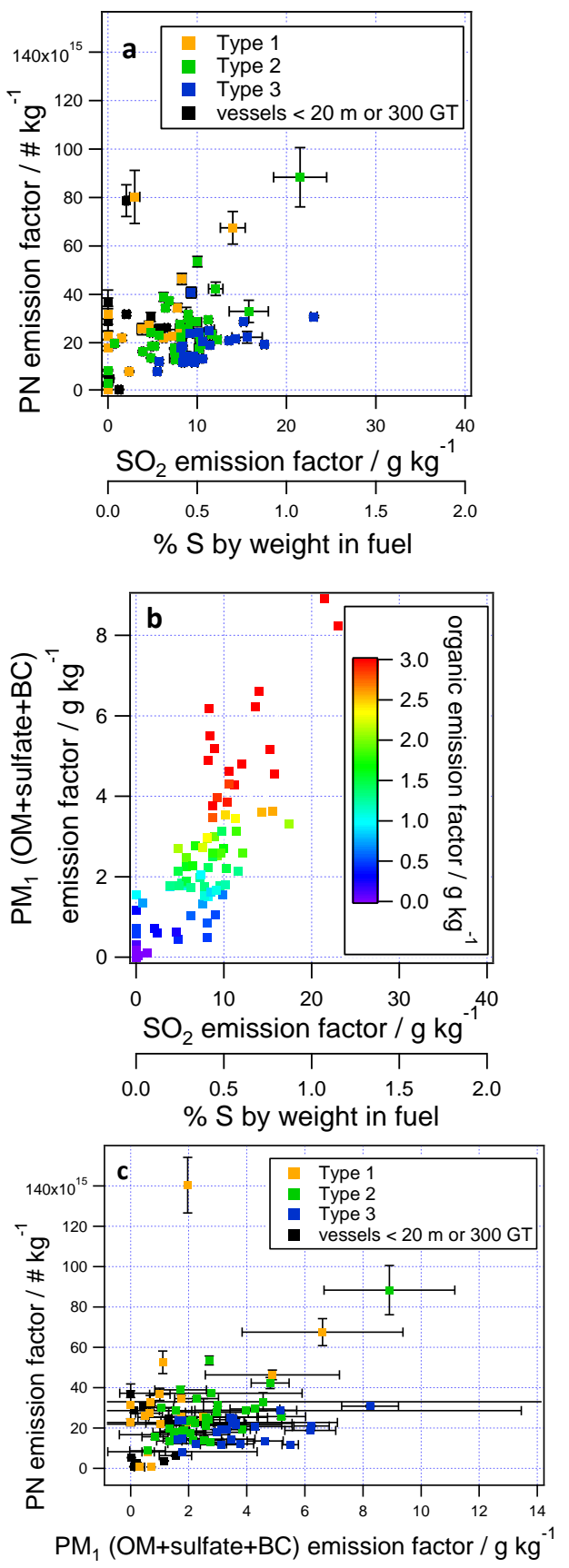

Fig. 5. Correlation of the particle number (a) and the submicron aerosol mass $\left(\mathrm{PM}_{1}\right)$ emission factors $(\mathbf{b})$ with sulfur dioxide emission factors which are associated with the weight percentage of fuel sulfur. Additionally, the particle number versus $\mathrm{PM}_{1}$ emission factors are shown (c). While graphs (a) and (c) are colored dependent on the vessel type ("Type 1": orange, "Type 2": green, "Type 3": blue, those not registered by the AIS system: black), the graph (b) is color-coded with the organic mass concentration emission factors. The graphs indicate that with increasing fuel sulfur content, the particle number as well as $\mathrm{PM}_{1}$ mass emission factors increase. Error bars were determined by means of Gaussian error propagation. containing aerosol particles are mainly formed after release from the stack (Lack et al., 2009).

Analysis of the submicron aerosol (average $\mathrm{PM}_{1} \mathrm{EF}$ for all vessels: $2.4 \pm 1.8 \mathrm{~g} \mathrm{~kg}^{-1}$, see Table 2) shows that sulfate $\mathrm{EFs}\left(\mathrm{EF}_{\mathrm{SO}_{4}}\right.$ (sulfur[\%]) $\left[\mathrm{g} \mathrm{kg}^{-1}\right]=0.06+0.3 \cdot \operatorname{sulfur}[\%]$, $R=0.67)$ as well as $\mathrm{OM} \mathrm{EFs}\left(\mathrm{EF}_{\mathrm{Org}}(\operatorname{sulfur}[\%])\left[\mathrm{g} \mathrm{kg}^{-1}\right.\right.$ ] $=0.06+4.4$. sulfur[\%], $R=0.85$ ) are strongly linearly correlated with the fuel sulfur content (see Fig. 5b). While the relation between fuel sulfur content, $\mathrm{SO}_{2}$ and $\mathrm{SO}_{4}$ is obvious, the increase of the organics $\mathrm{EF}$ with increasing fuel sulfur content can be explained as follows: in the cylinders of the engine a fraction of the lubricating oil for neutralizing acidic products to prevent corrosion is consumed. The higher the fuel sulfur content the more lubricating oil is needed (Lack et al., 2009) and consequently emitted. Additionally, the quantity of lubricating oil use likely depends on the engine type and performance. Therefore, OM EFs (average value for all vessels: $1.8 \pm 1.7 \mathrm{~g} \mathrm{~kg}^{-1}$, see Table 2) for individual ships likely depend on on the engine type and the amount of unburned fuel, i.e. the efficiency of combustion. In contrast to studies which were not performed in an ECA (Lack et al., 2009; Moldanova et al., 2009) we found OM but not sulfate (average EF: $0.54 \pm 0.46 \mathrm{~g} \mathrm{~kg}^{-1}$ ) to be the most abundant submicron aerosol species (see Fig. 6). While OM accounts for $72 \%$ averaged over all vessels sulfate amounts to $22 \%$ of the $\mathrm{PM}_{1}$ mass. The fraction of black carbon EFs to total $\mathrm{PM}_{1}$ amounts to $6 \%$ considering all vessels. In summary, $\mathrm{PM}_{1}$ emissions depend on fuel sulfur content with $\mathrm{EF}_{\mathrm{PM}_{1}}$ (sulfur[\%]) $\left[\mathrm{g} \mathrm{kg}^{-1}\right]=0.19+6.1 \cdot \operatorname{sulfur}[\%]$, $R=0.80$, see Fig. $5 \mathrm{~b}$ ) and potentially on the engine type and engine operating conditions. Further insights into the AMS mass spectral signatures indicate typical fragments of diesel exhaust organic and sulfate matter which result from unburned fuel and lubricating oil.

Polycyclic aromatic hydrocarbons: PAHs are aromatic compounds formed frequently during incomplete combustion processes. As some PAHs are classified as human carcinogens, PAHs are important to be considered. Generally, a more incomplete combustion process leads to increased EFs of PAH and BC. For this reason, PAH EFs positively correlate with BC EFs (EFPAH $\left(\mathrm{EF}_{\mathrm{BC}}\left[\mathrm{g} \mathrm{kg}^{-1}\right]\right)\left[\mathrm{g} \mathrm{kg}^{-1}\right]$ $\left.=0.003+0.02 \cdot \mathrm{EF}_{\mathrm{BC}}\left[\mathrm{g} \mathrm{kg}^{-1}\right], R=0.57\right)$. Due to different volatilities of these compounds their presence in the particle phase depends also on the exhaust temperature (Moldanova et al., 2009). However, with an average EF of $5.3 \pm 4.7$ $\mathrm{mg} \mathrm{kg}^{-1}$ for all vessels, PAHs account on average for $0.2 \%$ of the total emitted submicron aerosol mass.

Particle size distributions: the particle number size distribution EFs of the measured ship emission plumes covered the size range from 6 to $250 \mathrm{~nm}$ (see Fig. 7). The relatively fresh ship exhaust particle number size distributions are characterized by either uni- or bi-modal structures. One mode is centered at around $10 \mathrm{~nm}$, the second one at $35 \mathrm{~nm}$; in addition increased particle concentrations are found around $150 \mathrm{~nm}$ (brown, Fig. 7) particle mobility diameter. However, 

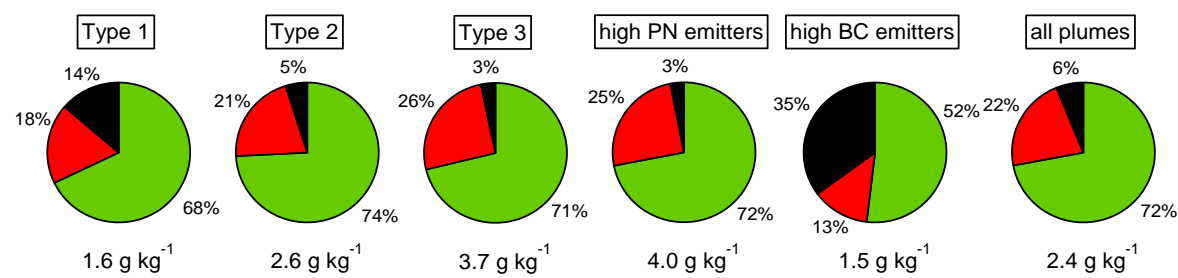

Fig. 6. Averaged chemical $\mathrm{PM}_{1}$ composition for the classified “Type 1", “Type 2", “Type 3" vessels, high PN/BC emitters and for all plumes calculated using total and chemically specified $\mathrm{PM}_{1}$ EFs. The $\mathrm{PM}_{1}$ composition of all vessel plumes includes organics (green), sulfate (red) and black carbon (black) while organic matter is the most abundant $\mathrm{PM}_{1}$ fraction. Sulfate species represent the second most abundant aerosol fraction beside for the high BC emitters.

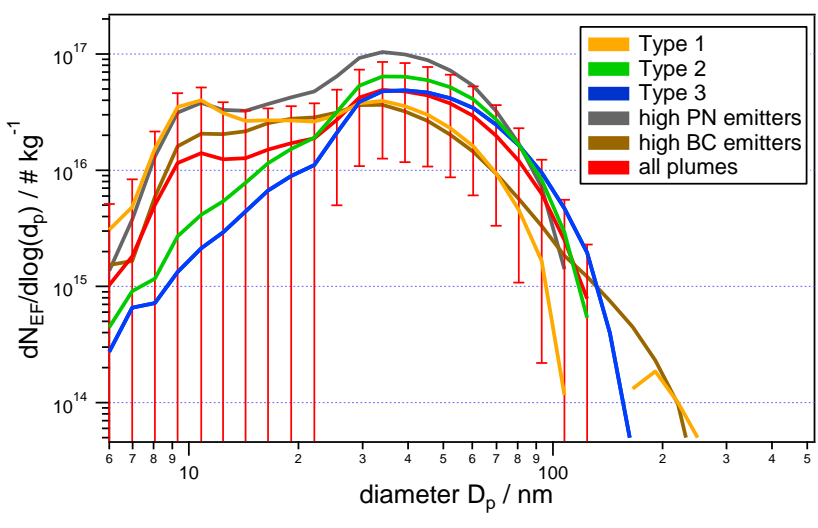

Fig. 7. Averaged size-resolved particle number emission factors in the 6 up to $523 \mathrm{~nm}$ size range for the three types of ship plumes, high PN/BC emitters and for all plumes measured during the campaign. Error bars represent the variability (standard deviation) within the ship plumes for each size bin.

as shown in Fig. 7 for all vessel plumes (red), the majority of plumes exhibit the bimodal size distribution only with average mode diameters at 10 and $35 \mathrm{~nm}$. Larger than $250 \mathrm{~nm}$, no significant increase of the particle number concentration compared to the background aerosol was found.

The intensity of the first mode, the nucleation mode varies strongly dependent on the type of vessel. The strong variations in particle number EFs of the nucleation mode can be explained by the different kind of fuels the vessels used and the different engine types (efficiency of operation and combustion). The formation of $\mathrm{H}_{2} \mathrm{SO}_{4}$, the most important new particle formation precursor, depends on the sulfur content in the fuel and the engine operation conditions. The efficiency of coagulation and condensation of freshly formed particles before emission from the stack differ for the individual vessels for which reason nucleation mode particles vary in size from $10-20 \mathrm{~nm}$.

The second mode, the so-called combustion aerosol mode (Petzold et al., 2008) centered around $35 \mathrm{~nm}$ is present in most size distributions of the measured vessel plumes and exhibits the largest particle number EFs values (Fig. 7). As the combustion aerosol mode contains combustion particles with a non-volatile core of elemental carbon, OM and ash, lower variations in the level of particle number EFs were observed, because non-volatile PM does not depend strongly on engine load (Petzold et al., 2008).

The particle number EF decreases for particles larger than $100 \mathrm{~nm}$ and is typically 3 orders of magnitude lower in relation to the combustion aerosol mode (Fig. 7). The intensity of this "exhaust particle contribution" increases with decreasing speed of the vessels implying a more incomplete combustion process and a simultaneous increase of black carbon. As only a small number of high black carbon emitters was measured, the average particle number EFs for all plumes in Fig. 7 (red) did not show this contribution.

\subsection{Characterization of the different vessel classes}

Table 2 summarizes averaged AIS data and chemical, physical as well as gas phase EFs which are explained in the following for all vessel classes. As three vessels are characterized by both, high particle number as well as black carbon EFs they were neither considered as "high PN emitters" nor "high BC emitters".

Comparison of number and black carbon EFs (see Fig. 4): "High PN emitters" are characterized by high number and typically moderate black carbon EFs. "High BC emitters" show a completely different behavior - they exhibit high black carbon and moderate particle number EFs. Higher black carbon concentrations imply a larger surface area where potential new particle formation precursors preferentially condense onto instead of nucleating. Additionally, high black carbon emissions inhibit the growth of freshly formed particles as they are scavenged while coagulating. For this reason, "high BC emitters" exhibit moderate particle number EFs only and vice versa. While "Type 1" vessels exhibit largest $\mathrm{BC}$ and PN EFs, with increasing gross tonnages of the "Type 2" and "Type 3" vessels, PN and BC EFs decreased, on average. For "Type 3" vessels, particle number and black carbon EFs are proportional within the measurement uncertainty and relatively low in contrast to "Type 1" and "Type 2" vessels. Lower particle number and black carbon EFs 
can be explained by a more complete combustion which implies higher combustion temperatures. High BC EFs instead are found for those vessels with typically lower vessel speeds and therefore possibly a more incomplete combustion. In contrast to "high PN emitters" and "high BC emitters" that both are characterized by small average gross tonnages, lengths and engine powers, "Type 3" vessels with an average length of $286 \mathrm{~m}$ reflect the largest ocean-going vessels passing the Elbe. For this reason, the engine systems of these ships likely differ from those of the smaller "Type 1 " and "Type 2" vessels. Additionally, the exhaust system of the "Type 3" vessels is larger therefore we suggest that due to an increased residence time of the aerosol in the ship exhaust system transformation (coagulation and condensation) processes occur increased. These processes likely result in smaller particle number EFs compared to "Type 1" and "Type 2" vessels.

Comparison of $\mathrm{SO}_{2}$ and $\mathrm{NO}_{x}$ EFs: the average EFs of both, $\mathrm{SO}_{2}$ and $\mathrm{NO}_{\mathrm{x}}$ gas phase species are higher for "high PN emitters" and "Type 3" vessels compared to "high BC emitters". Additionally, with increasing gross tonnage levels ("Type 1", "Type 2", "Type 3") $\mathrm{SO}_{2}$ and $\mathrm{NO}_{\mathrm{x}}\left(\mathrm{NO}, \mathrm{NO}_{2}\right.$ and $\mathrm{NO} / \mathrm{NO}_{2}$ ) EFs increase (Table 2). $\mathrm{SO}_{2}$ emissions depend on the sulfur content in the fuel which also has an impact on the particle number concentrations by production of sulfuric acid (Fig. 5a). Additionally, as shown in Fig. 5a, PN EFs did not only depend on the fuel sulfur content but also on the classified vessel types. In contrast, $\mathrm{NO}_{\mathrm{x}}\left(\mathrm{NO}, \mathrm{NO}_{2}\right)$ is generated by high-temperature oxidation processes with nitrogen in air. For this reason, $\mathrm{NO}_{\mathrm{x}}$ EFs are combustion temperaturedependent. The higher $\mathrm{NO}_{\mathrm{x}} \mathrm{EFs}$ and the $\mathrm{NO} / \mathrm{NO}_{2}$ ratios of the larger vessels are potentially due to higher combustion temperatures within their engines.

Comparison of $P M_{1}$ EFs: the particle number EFs tend to increase with increasing $\mathrm{PM}_{1} \mathrm{EFs}$ (Fig. $5 \mathrm{c}$; $\mathrm{EF}_{\mathrm{CPC}}$ $\left(\mathrm{EF}_{\mathrm{PM}_{1}}\left[\mathrm{~g} \mathrm{~kg}^{-1}\right]\right)\left[\# \mathrm{~kg}^{-1}\right]=1.7 e+16+3.0 e+15 \cdot \mathrm{EF}_{\mathrm{PM}_{1}}$ $\left[\mathrm{g} \mathrm{kg}^{-1}\right], R=0.30$ ) as the ship emissions are characterized by similar size distribution shapes or rather similar ratio of smaller/larger particles. $\mathrm{PM}_{1}$ EFs increase from "Type 1" over "Type 2" to "Type 3" vessels (Fig. 5c and Table 2). Regarding the averaged chemical composition (see Fig. 6), $\mathrm{OM}$ was found as the most abundant submicron aerosol fraction for all types of vessels while sulfate is the second most abundant fraction in $\mathrm{PM}_{1}$ with $\sim 22 \%$. In contrast, due to the incomplete combustion conditions of "high BC emitters", the black carbon fraction (35\%) is more abundant than the sulfate fraction $(13 \%)$ for this type of vessels. Likewise to the BC EFs, PAH EFs anti-correlate with the vessel size (smallest PAH EFs for "Type 3" vessels) due to the strong dependence of this value on the combustion process efficiency.

Comparison of size distributions: comparing the size distributions and EFs for particle components of the different vessel types we found the size of the ship engine exhaust aerosol to show some dependency on the size of vessel that was probed. Although several factors like fuel qual- ity, engine type, efficiency of combustion, cooling and dilution of the exhaust or the design of the exhaust system likely affect size distributions, general differences between the different vessel types can be identified in Fig. 7. Smaller "Type 1" vessels, "high PN emitters" and "high BC emitters" emit particulate matter composed of freshly formed particles likely from sulfuric acid nucleating in the expanding plume (mode around $10 \mathrm{~nm}$ ) and combustion aerosol particles (mode around $35 \mathrm{~nm}$ ). Larger fuel sulfur contents imply higher sulfate and organic EFs for which reason both modes are more pronounced for "high PN emitters". In contrast, "high BC emitters" exhibit clearly enhanced concentrations for particles larger than $100 \mathrm{~nm}$ compared to the other vessel types. This enhancement of concentrations could possibly originate from large soot particles which were deposited on walls of the exhaust tube system and are then re-entrained into the exhaust gas stream. "Type 2" and "Type 3" vessels show a totally different behavior with a less pronounced nucleation mode and no increase for particles larger than $100 \mathrm{~nm}$, reflecting both, the lower number and BC EFs. The average plumes for all vessel types, exhibited the combustion aerosol mode $(\sim 35 \mathrm{~nm})$ likely including a non-volatile core of EC, OM or ash. With increasing gross tonnage levels implying "Type 1", "Type 2" and "Type 3" vessels, larger mode diameters were found (Table 2).

\section{Discussion with respect to previous studies}

The fact that the formation of new particles increases in line with $\mathrm{SO}_{2}$ emissions via the formation of $\mathrm{SO}_{3}$ and $\mathrm{H}_{2} \mathrm{SO}_{4}$ indicates that the fuel quality, i.e. the sulfur content in the fuel, has an important impact on particle number EFs as also mentioned in several other studies of passenger car and ship emissions (Schneider et al., 2005; Chen et al., 2005; Lu et al., 2006; Petzold et al., 2008). For this reason, limiting the fuel sulfur content can result in a direct reduction of the particle number emissions. However, as already pointed out by Lack et al. (2009), we also assume that beside the fuel type, the engine type and operation conditions (efficiency of combustion) and probably the engine and exhaust system play important roles. The average particle number EF of $2.55 e+16 \# \mathrm{~kg}^{-1}$ for all vessels during this study is within the range presented in the literature varying from $0.4 e+16$ to $6.2 e+16 \# \mathrm{~kg}^{-1}$ (Hobbs et al., 2000; Chen et al., 2005; Lack et al., 2009; Murphy et al., 2009). A very similar average particle number $\mathrm{EF}$ as our average value was reported by Jonsson et al. (2011) who measured and evaluated particle number and mass EFs also in an ECA. However, our average $\mathrm{SO}_{2}$ emission factor of $7.7 \mathrm{~g} \mathrm{~kg}^{-1}$ which corresponds to an average fuel sulfur content of $0.4 \%$ is lower compared to those in non-ECA studies which probed ships burning heavy fuel oil with an average fuel sulfur content of $2.7 \%$ (Corbett and Koehler, 2003; Endresen et al., 2003). 
We found a positive correlation between the particle number EFs, fuel sulfur and $\mathrm{PM}_{1} \mathrm{EFs}$. OM is the most abundant $\mathrm{PM}_{1}$ fraction (average of $72 \%$ ): On the one hand, OM increases with increasing $\mathrm{SO}_{4}$ (average contribution to $\mathrm{PM}_{1}$ : $22 \%$ ) as more cylinder lubricating oil is needed to neutralize corrosive sulfur species. On the other hand, OM emissions depend on the type of engine and the operation conditions as unburned fuel increases the organic emissions as well as those of black carbon. The average contribution of black carbon to $\mathrm{PM}_{1}$ emissions was $6 \%$, similar to the $4 \%$ measured by Sinha et al. (2003). Our studies show that black carbon depends on the vessel speed and therefore likely engine load and operation conditions, which might influence the degree of incomplete combustion. For this reason, not only the fuel sulfur content has a significant impact on total $\mathrm{PM}_{1}$, also the engine type and operation additionally play important roles. The observed PM composition clearly differs from those by Lack et al. (2009) who reported $46 \%$ particulate $\mathrm{SO}_{4}, 39 \%$ $\mathrm{OM}$ and $15 \% \mathrm{BC}$ for 211 encountered commercial and private marine vessels in the Gulf of Mexico. Due to the limitation of the fuel sulfur to $1 \%$ by weight, in the ECA in this study higher OM than sulfate EFs were measured. As a consequence of the reduced fuel sulfur contents, the reduction of sulfate EFs leads to a less acidic aerosol which positively affects the environment and the aerosol chemistry and therefore climate when considering the formation

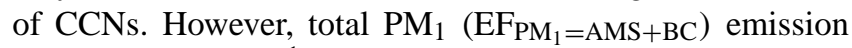
factors of $3.3 \mathrm{~g} \mathrm{~kg}^{-1}$ found by Lack et al. (2009) are comparable with the $2.4 \mathrm{~g} \mathrm{~kg}^{-1}$ observed during this study. In comparison, Jonsson et al. (2011) who also conducted measurements in an ECA in Scandinavia reported an average $\mathrm{EF}_{\mathrm{PM}}(5.6-560 \mathrm{~nm})$ of $2.0 \mathrm{~g} \mathrm{~kg}^{-1}$ determined for 734 individual ships. For this reason, both, particulate mass and number EFs are well comparable with those received under similar conditions (Jonsson et al., 2011) and, as expected, they are lower than the global average values of $5.9-7.6 \mathrm{~g} \mathrm{~kg}^{-1}$ (Endresen et al., 2003; Eyring et al., 2005b).

When comparing black carbon and particle number emissions of the ships a totally different behavior of both features was observed. Similar as shown by Ban-Weiss et al. (2009) for individual heavy-duty trucks we found minimal overlap between both high black carbon emitters and high particle number emitters due to the fact that increased black carbon emissions suppress new particle formation (Kerminen et al., 2001; Monkkonen et al., 2004). This relationship between the emission levels for both variables is also reflected in the associated size distributions. An increased availability of sulfuric acid tends to result in an increase of nucleation mode particles as also mentioned by Petzold et al. (2008). In contrast, high black carbon emitters exhibit increased particle concentrations for particles larger than $100 \mathrm{~nm}$ as also mentioned in studies performed by Petzold et al. (2010). Sinha et al. (2003) as well as Petzold et al. (2008) who analyzed black carbon mass EFs from cruising ships reported an $\mathrm{EF}_{\mathrm{BC}}$ of about $0.18 \mathrm{~g} \mathrm{~kg}^{-1}$ which is slightly larger than the average $\mathrm{EF}_{\mathrm{BC}}$ of $0.15 \mathrm{~g} \mathrm{~kg}^{-1}$ determined for all measured plumes during this study. We found that for enhanced black carbon EFs, $\mathrm{NO}_{\mathrm{x}}$ EFs drop by up to $50 \%$. Lower combustion temperatures lead to a decrease in $\mathrm{NO}, \mathrm{NO}_{2}$ and $\mathrm{NO}_{\mathrm{x}}$ EFs (Sinha et al., 2003) and the $\mathrm{NO} / \mathrm{NO}_{2}$ ratio because under these conditions the oxidation of nitrogen is less favored. For this reason, a large range of $\mathrm{NO}_{\mathrm{x}} \mathrm{EFs}$ (average $\mathrm{EF}_{\mathrm{NO}_{\mathrm{x}}}=53 \pm 27 \mathrm{~g} \mathrm{~kg}^{-1}$ ) from 20 to over $100 \mathrm{~g} \mathrm{~kg}^{-1}$ were reported in the literature (Hobbs et al., 2000; Sinha et al., 2003; Chen et al., 2005; Williams et al., 2009).

Vessels with a gross tonnage of less than 5000 ("Type 1") exhibit the largest black carbon and particle number EFs. Due to the different setup of the ship engine system, its performance and exhaust tubes, emissions of larger vessels ("Type 3") commonly differ strongly from those of smaller vessels. For this reason, in addition to several other quantities the gross tonnage is an important factor distinguishing different kinds of vessels in terms of emission characteristics as also mentioned by Hulskotte et al. (2010). Comparing "high PN emitters" with the largest ocean-going vessels characterized by gross tonnages of more than 30000 ("Type 3"), similar EFs for all particulate physical and chemical as well as trace gas quantities were found. The only exception is the average particle number EF of the large vessels which amounts to only a third compared to those of the smaller ships. This difference is reflected in the average size distributions with less distinct nucleation modes for the larger vessels, on average. We suggest that the aerosol in the larger exhaust tube systems of the large ships has more time to coagulate and thus to reduce the number concentrations of very small particles. $\mathrm{PM}_{1}$ mass EFs instead are similar for "high PN emitters" and "Type 3" vessels and investigated size distributions did not show enhanced EFs of particles above $100 \mathrm{~nm}$. This feature was also found by Hobbs et al. (2000), Murphy et al. (2009), Petzold et al. (2008) and Kasper et al. (2007) who investigated size distributions of marine diesel engine emissions and measured major modes in the $10-100 \mathrm{~nm}$ size range but hardly any particles larger than $250 \mathrm{~nm}$. Also, the PAH EFs depend on the gross tonnage of the vessels: While smaller vessels exhibit larger PAH EFs, the decrease of PAH EFs with increasing vessel size can be explained by a more incomplete combustion process in the smaller "Type 1" vessels. For this reason, in contrast to all other EFs of the registered quantities $\left(\mathrm{NO}, \mathrm{NO}_{2}, \mathrm{NO}_{\mathrm{x}}, \mathrm{SO}_{2}\right.$, $\mathrm{SO}_{4}$, Org, $\mathrm{PM}_{1}$ ) which increase with increasing gross tonnages (i.e. from "Type 1" over "Type 2" to "Type 3" vessels) the number, black carbon and PAH EFs decrease when larger vessels were probed.

\section{Summary and conclusions}

Chemical, physical and gas phase species were measured in a large number of commercial marine vessel plumes on the banks of the Lower Elbe in April 2011. During the 5 days of 
sampling 139 ship emission plumes were of sufficient quality to be analyzed providing emission factors. The information of Automated Identification System broadcasts for the vessels allows providing a detailed characterization of variables affecting gas and particulate emissions.

Total particle number EFs were found to increase with increasing fuel sulfur content. Additionally, the exhaust system appears to affect the particle number EFs. Smaller particle number EFs were observed for larger vessels, possibly due to enhanced coagulation in the exhaust system of the larger engines and the more efficient combustion process due to higher combustion temperatures. For these reasons, the particle number EFs depend on a variety of variables like fuel composition as well as engine type, operation and exhaust system.

Similar dependences (on fuel sulfur content, engine type and load) were found for the emission factors of particulate matter and particle chemical components which are dominated by OM, sulfate and black carbon. The EFs of the most abundant $\mathrm{PM}_{1}$ fraction, the organic matter are positively correlated with EFs of sulfate, which in turn depend on the fuel sulfur content. In addition, $\mathrm{OM}$ is also dependent on engine type and load because it is strongly associated with unburned fuel and lubricating oil. Black carbon emissions appear to be mainly a function of the engine type. While contributing only to a minor degree to $\mathrm{PM}_{1}$ on average, black carbon concentrations in the emissions have a strong impact on particle number EFs. PAHs instead account for $0.2 \%$ of the emitted submicron aerosol mass and are larger the smaller the vessels are.

The measurements performed during this study also show an increase of $\mathrm{SO}_{2}$ and $\mathrm{NO}_{\mathrm{x}}$ mixing ratios while $\mathrm{O}_{3}$ significantly decreased due to reactions with $\mathrm{NO}$ when ships passed the site. While $\mathrm{SO}_{2}$ is directly related to fuel sulfur content, $\mathrm{NO}, \mathrm{NO}_{2}$ and $\mathrm{NO}_{\mathrm{x}} \mathrm{EFs}$ increase with increased combustion temperatures.

The size distributions of the ship plume aerosol also show a dependence on fuel sulfur content. The intensity of the nucleation mode from freshly formed particles in the 10-20 nm diameter range depends on the sulfur content in the fuel, the engine and the size of the exhaust system which likely reduces small particles by coagulation and condensation processes. While the combustion aerosol mode in the $35 \mathrm{~nm}$ size range was measured for all types of vessels, vessels characterized by large black carbon EFs additionally show increased concentrations for particles above $100 \mathrm{~nm}$ particle diameter. Generally the exhaust particle size distributions are influenced by numerous factors including the engine power and sulfur content in the fuel, as well as likely cooling and dilution of the exhaust gases.

In summary, emission factors of particle number concentrations and size distributions, the submicron particle chemical components and total submicron particulate matter as well as the trace gas mixing ratios depend on a multitude of factors including fuel sulfur content and probably the size of the ship exhaust system. Other factors that are expected to influence emission factors are engine type, load and performance. However, these relationships could not be shown in this study. Especially fuel sulfur regulations, as adopted within the emission control areas next to populated regions, directly affect local climate, air quality and health.

As there are many factors that influence ship emissions and still only few measurements of these under real world conditions, the work presented here is valuable for the investigation of the influence of ship emissions on air quality in an emission control area. Additionally, the work presented here is clearly useful for comparing emission factors with those from non-ECA studies as data on ship emissions measured in ECAs are still sparse. Although emission factors were evaluated for a range of vessels and measured quantities, due to the limited AIS information on e.g. engine type, engine load or propulsion system, the presented emission factors generally reflect emission factors for average ships of certain size ranges, useful e.g. for estimating global or bulk emissions for ECAs. These results are not suitable for detailed case studies, estimating e.g. emission changes when changing the fleet composition.

Acknowledgements. This research was partially funded by the German Research Foundation (DFG, GRK 826) and internal sources from the Max-Planck Society. The authors wish to acknowledge T. Böttger for technical support and J. Schneider for helpful discussions. We gratefully acknowledge the NOAA Air Resources Laboratory (ARL) for the provision of the HYSPLIT transport and dispersion model.

The service charges for this open access publication have been covered by the Max Planck Society.

Edited by: R. Ebinghaus

\section{References}

Agrawal, H., Welch, W. A., Miller, J. W., and Cocker, D. R.: Emission measurements from a crude oil tanker at sea, Environ. Sci. Technol., 42, 7098-7103, 2008.

Agrawal, H., Eden, R., Zhang, X., Fine, P. M., Katzenstein, A., Miller, J. W., Ospital, J., Teffera, S., and Cocker, D. R.: Primary Particulate Matter from Ocean-Going Engines in the Southern California Air Basin, Environ. Sci. Technol., 43, 5398-5402, 2009.

Ault, A. P., Gaston, C. J., Wang, Y., Dominguez, G., Thiemens, M. H., and Prather, K. A.: Characterization of the Single Particle Mixing State of Individual Ship Plume Events Measured at the Port of Los Angeles, Environ. Sci. Technol., 44, 1954-1961, 2010.

Ban-Weiss, G. A., Lunden, M. M., Kirchstetter, T. W., and Harley, R. A.: Measurement of Black Carbon and Particle Number Emission Factors from Individual Heavy-Duty Trucks, Environ. Sci. Technol., 43, 1419-1424, 2009. 
Beirle, S., Platt, U., von Glasow, R., Wenig, M., and Wagner, T.: Estimate of nitrogen oxide emissions from shipping by satellite remote sensing, Geophys. Res. Lett., 31, L18102, doi:10.1029/2004GL020312, 2004.

Chen, G., Huey, L. G., Trainer, M., Nicks, D., Corbett, J., Ryerson, T., Parrish, D., Neuman, J. A., Nowak, J., Tanner, D., Holloway, J., Brock, C., Crawford, J., Olson, J. R., Sullivan, A., Weber, R., Schauffler, S., Donnelly, S., Atlas, E., Roberts, J., Flocke, F., Hubler, G., and Fehsenfeld, F.: An investigation of the chemistry of ship emission plumes during ITCT 2002, J. Geophys. Res. Atmos., 110, doi:10.1029/2004JD005236, 2005.

Cooper, D. A.: Exhaust emissions from high speed passenger ferries, Atmos. Environ., 35, 4189-4200, 2001.

Corbett, J. J. and Fischbeck, P.: Emissions from ships, Science, 278, 823-824, 1997.

Corbett, J. J. and Koehler, H. W.: Updated emissions from ocean shipping, J. Geophys. Res.-Atmos., 108, doi:10.1029/2003JD003751, 2003.

Corbett, J. J., Fischbeck, P. S., and Pandis, S. N.: Global nitrogen and sulfur inventories for oceangoing ships, J. Geophys. Res.Atmos., 104, 3457-3470, 1999.

Durkee, P. A., Chartier, R. E., Brown, A., Trehubenko, E. J., Rogerson, S. D., Skupniewicz, C., Nielsen, K. E., Platnick, S., and King, M. D.: Composite ship track characteristics, J. Atmos. Sci., 57, 2542-2553, 2000.

Dusek, U., Frank, G. P., Hildebrandt, L., Curtius, J., Schneider, J., Walter, S., Chand, D., Drewnick, F., Hings, S., Jung, D., Borrmann, S., and Andreae, M. O.: Size matters more than chemistry for cloud-nucleating ability of aerosol particles, Science, 312, 1375-1378, 2006.

Drewnick, F., Böttger, T., von der Weiden-Reinmüller, S.-L., Zorn, S. R., Klimach, T., Schneider, J., and Borrmann, S.: Design of a mobile aerosol research laboratory and data processing tools for effective stationary and mobile field measurements, Atmos. Meas. Tech., 5, 1443-1457, doi:10.5194/amt-5-1443-2012, 2012.

Endresen, O., Sorgard, E., Sundet, J. K., Dalsoren, S. B., Isaksen, I. S. A., Berglen, T. F., and Gravir, G.: Emission from international sea transportation and environmental impact, J. Geophys. Res. Atmos., 108, doi:10.1029/2002JD002898, 2003.

Eyring, V., Kohler, H. W., Lauer, A., and Lemper, B.: Emissions from international shipping: 2 . Impact of future technologies on scenarios until 2050, J. Geophys. Res. Atmos., 110, doi:10.1029/2004JD005620, 2005a.

Eyring, V., Kohler, H. W., van Aardenne, J., and Lauer, A.: Emissions from international shipping: 1 . The last 50 years, J. Geophys. Res. Atmos., 110, doi:10.1029/2004JD005619, 2005b.

Eyring, V., Isaksen, I. S. A., Berntsen, T., Collins, W. J., Corbett, J. J., Endresen, O., Grainger, R. G., Moldanova, J., Schlager, H., and Stevenson, D. S.: Transport impacts on atmosphere and climate: Shipping, Atmos. Environ., 44, 4735-4771, 2010.

Fridell, E., Steen, E., and Peterson, K.: Primary particles in ship emissions, Atmos. Environ., 42, 1160-1168, 2008.

Healy, R. M., O’Connor, I. P., Hellebust, S., Allanic, A., Sodeau, J. R., and Wenger, J. C.: Characterisation of single particles from in-port ship emissions, Atmos. Environ., 43, 6408-6414, 2009.

Hinds, C.: Aerosol technology: properties, behavior, and measurement of airborne particles, John Wiley \& Sons, New York, 1999.
Hobbs, P. V., Garrett, T. J., Ferek, R. J., Strader, S. R., Hegg, D. A., Frick, G. M., Hoppel, W. A., Gasparovic, R. F., Russell, L. M., Johnson, D. W., O’Dowd, C., Durkee, P. A., Nielsen, K. E., and Innis, G.: Emissions from ships with respect to their effects on clouds, J. Atmos. Sci., 57, 2570-2590, 2000.

Huffman, J. A., Jayne, J. T., Drewnick, F., Aiken, A. C., Onasch, T., Worsnop, D. R., and Jimenez, J. L.: Design, modeling, optimization, and experimental tests of a particle beam width probe for the aerodyne aerosol mass spectrometer, Aerosol Sci. Technol., 39, 1143-1163, 2005.

Hulskotte, J. H. J. and van der Gon, H. A. C. D.: Fuel consumption and associated emissions from seagoing ships at berth derived from an on-board survey, Atmos. Environ., 44, 1229-1236, 2010.

Jonsson, A. M., Westerlund, J., and Hallquist, M.: Size-resolved particle emission factors for individual ships, Geophys. Res. Lett., 38, doi:10.1029/2011GL047672, 2011.

Kasper, A., Aufdenblatten, S., Forss, A., Mohr, M., and Burtscher, H.: Particulate emissions from a low-speed marine diesel engine, Aerosol Sci. Technol., 41, 24-32, 2007.

Kerminen, V. M., Pirjola, L., and Kulmala, M.: How significantly does coagulational scavenging limit atmospheric particle production?, J. Geophys. Res. Atmos., 106, 24119-24125, 2001.

Lack, D. A., Corbett, J. J., Onasch, T., Lerner, B., Massoli, P., Quinn, P. K., Bates, T. S., Covert, D. S., Coffman, D., Sierau, B., Herndon, S., Allan, J., Baynard, T., Lovejoy, E., Ravishankara, A. R., and Williams, E.: Particulate emissions from commercial shipping: Chemical, physical, and optical properties, J. Geophys. Res. Atmos., 114, D00F04, doi:10.1029/2008JD011300, 2009.

Lawrence, M. G. and Crutzen, P. J.: Influence of NOx emissions from ships on tropospheric photochemistry and climate, Nature, 402, 167-170, 1999.

Lu, G., Brook, J. R., Alfarra, M. R., Anlauf, K., Leaitch, W. R., Sharma, S., Wang, D., Worsnop, D. R., and Phinney, L.: Identification and characterization of inland ship plumes over Vancouver, BC, Atmos. Environ., 40, 2767-2782, 2006.

Lyyranen, J., Jokiniemi, J., Kauppinen, E. I., and Joutsensaari, J.: Aerosol characterisation in medium-speed diesel engines operating with heavy fuel oils, J. Aerosol Sci., 30, 771-784, 1999.

Moldanova, J., Fridell, E., Popovicheva, O., Demirdjian, B., Tishkova, V., Faccinetto, A., and Focsa, C.: Characterisation of particulate matter and gaseous emissions from a large ship diesel engine, Atmos. Environ., 43, 2632-2641, 2009.

Monkkonen, P., Koponen, I. K., Lehtinen, K. E. J., Uma, R., Srinivasan, D., Hameri, K., and Kulmala, M.: Death of nucleation and Aitken mode particles: observations at extreme atmospheric conditions and their theoretical explanation, J. Aerosol Sci., 35, 781787, 2004.

Murphy, S. M., Agrawal, H., Sorooshian, A., Padro, L. T., Gates, H., Hersey, S., Welch, W. A., Jung, H., Miller, J. W., Cocker, D. R., Nenes, A., Jonsson, H. H., Flagan, R. C., and Seinfeld, J. H.: Comprehensive Simultaneous Shipboard and Airborne Characterization of Exhaust from a Modern Container Ship at Sea, Environ. Sci. Technol., 43, 4626-4640, 2009.

Osborne, S. R., Johnson, D. W., Bower, K. N., and Wood, R.: Modification of the aerosol size distribution within exhaust plumes produced by diesel-powered ships, J. Geophys. Res.-Atmos., 106, 9827-9842, 2001. 
Petzold, A., Hasselbach, J., Lauer, P., Baumann, R., Franke, K., Gurk, C., Schlager, H., and Weingartner, E.: Experimental studies on particle emissions from cruising ship, their characteristic properties, transformation and atmospheric lifetime in the marine boundary layer, Atmos. Chem. Phys., 8, 2387-2403, doi:10.5194/acp-8-2387-2008, 2008.

Petzold, A., Weingartner, E., Hasselbach, I., Lauer, P., Kurok, C., and Fleischer, F.: Physical Properties, Chemical Composition, and Cloud Forming Potential of Particulate Emissions from a Marine Diesel Engine at Various Load Conditions, Environ. Sci. Technol., 44, 3800-3805, 2010.

Sarvi, A., Fogelholm, C. J., and Zevenhoven, R.: Emissions from large-scale medium-speed diesel engines: 2. Influence of fuel type and operating mode, Fuel Process Technol., 89, 520-527, 2008.

Schneider, J., Hock, N., Weimer, S., and Borrmann, S.: Nucleation particles in diesel exhaust: Composition inferred from in situ mass spectrometric analysis, Environ. Sci. Technol., 39, 61536161, 2005.
Sinha, P., Hobbs, P. V., Yokelson, R. J., Christian, T. J., Kirchstetter, T. W., and Bruintjes, R.: Emissions of trace gases and particles from two ships in the southern Atlantic Ocean, Atmos. Environ., 37, 2139-2148, 2003.

von der Weiden, S.-L., Drewnick, F., and Borrmann, S.: Particle Loss Calculator - a new software tool for the assessment of the performance of aerosol inlet systems, Atmos. Meas. Tech., 2, 479-494, doi:10.5194/amt-2-479-2009, 2009.

Williams, E. J., Lerner, B. M., Murphy, P. C., Herndon, S. C., and Zahniser, M. S.: Emissions of $\mathrm{NO}(\mathrm{x}), \mathrm{SO}(2), \mathrm{CO}$, and HCHO from commercial marine shipping during Texas Air Quality Study (TexAQS) 2006, J. Geophys. Res. Atmos., 114, doi:10.1029/2009JD012094, 2009. 